\title{
ARTICLES
}

\section{Virtual Witness Confrontation in Criminal Cases: A Proposal to Use Videoconferencing Technology in Maritime Piracy Trials}

\author{
Yvonne M. Dutton*
}

\begin{abstract}
Maritime piracy is a serious problem, yet states are not prosecuting captured pirates with any regularity. One of the many reasons cited to explain this phenomenon focuses on the expense and difficulty of mounting cases of such international proportions and which involve evidence, suspects, victims, and witnesses from around the globe. In an effort to help close the impunity gap that surrounds piracy, this Article offers a potential solution to the difficulties associated with obtaining live witness testimony. It proposes a rule to allow witnesses under some circumstances to testify remotely by way of two-way, live videoconferencing technology. While remote testimony need not become the norm in maritime piracy cases, the proposed rule is carefully structured to balance both the public's and the defendant's interest in a fair trial.
\end{abstract}

* Associate Professor, Indiana University Robert H. McKinney School of Law. 


\section{TABLE OF ConTENTS}

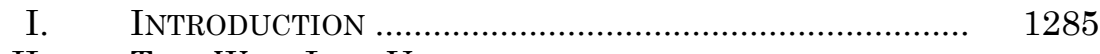

II. Two-WAY, LIVE VIDEOCONFERENCING

TECHNOLOGY (VCT)

1289

III. SOME APPROACHES USED TO ANALYZE WHEN

to Allow Prosecution Witnesses to Testify

BY TWO-WAY, LIVE VCT IN CRIMINAL TRIALS

A. Remote VCT Prosecution Testimony in

International Criminal Courts

1. The International Criminal Tribunal

for the Former Yugoslavia

2. The International Criminal Tribunal for Rwanda

3. The Special Court for Sierra Leone

4. The International Criminal Court

B. Remote VCT Prosecution Testimony in

Federal Courts in the United States.

1. U.S. Supreme Court Cases Guiding Lower Court Decisions on Whether to Admit Remote Adult ProsecutionWitness Testimony

a. Coy v. Iowa ............................................. 1305

b. Maryland v. Craig ................................ 1307

2. Federal Circuit Split on the Proper Test to Apply in Determining When to Permit Adult Prosecution Witnesses to Testify by Two-Way, Live VCT

3. The Supreme Court After Craig: Some Confrontation Clause Guidance, but No Resolution of the Circuit Split

IV. The Problem of Modern Maritime Piracy AND THE NEED TO ENCOURAGE STATES TO USE THE Available Laws to Prosecute Pirates INSTEAD OF RELEASING THEM

A. The Continuing Threat of Modern Maritime Piracy.

B. The International Law Authorizing Piracy

Prosecutions

C. The Tendency to Release, Rather than

Prosecute, Captured Pirates

D. The Need to Encourage More Piracy

Prosecutions by Improving Access to

Witness Testimony....

V. A Proposal to Allow Two-Way, LiVe VCT Witness Testimony in Maritime PiRAcy TRAils..... 
A. Testimony Necessary to the Fair and Just Resolution of the Case...

B. Witness Unable or Unwilling for Good Reason to Testify in Person

C. Transmission and Other Safeguards to Protect Defendant's Fair-Trial Rights

VI.

\section{INTRODUCTION}

Advancements in technology have now made it possible for courts around the globe to secure the testimony of witnesses remotely. Through two-way, live videoconferencing technology (VCT), a witness's image and voice can be transmitted from any location in the world to the courtroom where the trial is taking place. ${ }^{1}$ The benefits of using such technology can obviously be significant in circumstances where witnesses would have to travel great distances at great cost and at great inconvenience, while also risking their health or safety, to testify live at a trial. When seeking the testimony of foreign witnesses who are beyond the subpoena power of the court, the promise of remote testimony may be the only way to obtain that witness's cooperation and evidence. ${ }^{2}$

Notwithstanding that many commentators and courts seem to embrace the benefits of remote witness testimony in civil cases, ${ }^{3}$ not all agree on the propriety of allowing prosecution witnesses to testify by two-way, live VCT against defendants in criminal trials. The arguments against remote testimony in criminal trials include the

1. See Fredric I. Lederer, The Potential Use of Courtroom Technology in Major Terrorism Cases, 12 WM. \& MARY BILL RTS. J. 887, 907 (2004) [hereinafter Lederer, Courtroom Technology] (describing videoconferencing equipment and its increasing use in courtrooms); Fredric I. Lederer, The Road to the Virtual Courtroom? A Consideration of Today's-And Tomorrow's-High-Technology Courtrooms, 50 S.C. L. REV. 799, 802 (1999) [hereinafter Lederer, Virtual Courtroom] ("Given that judges, counsel, and witnesses need not be in the same location, there is a real possibility of trials in which no physical commonality is present.").

2. $\quad$ See Lynn Helland, Remote Testimony-A Prosecutor's Perspective, 35 U. MiCH. J.L. REFORM 719, 725 (2002) (stating that, from the author's perspective as a federal prosecutor for twenty years, although citizens of foreign countries will refuse to travel to the United States to testify, many have indicated they would be willing to accommodate less burdensome requests).

3. See Lederer, Courtroom Technology, supra note 1, at 906-07 (stating that remote witness testimony has been used in civil cases in both the United States and abroad); see also FED. R. CIV. P. 43(a) (authorizing the use of VCT in civil cases "[f]or good cause in compelling circumstances and with appropriate safeguards"). 
following: remote testimony may violate the defendant's right to be confronted with the evidence against him because the testimony is not "face-to-face"; ${ }^{4}$ remote testimony cannot ensure truthfulness to the same extent as requiring the witness to testify live before the defendant; ${ }^{5}$ and remote testimony does not provide the court and jury with the same opportunity as does live testimony to assess the demeanor and truthfulness of the witness. ${ }^{6}$ On the other hand, a number of courts have concluded that the "interests of justice" and other exceptional circumstances justify allowing some witnesses to testify remotely against defendants in criminal cases. Various international criminal courts have permitted two-way, live VCT in some cases when the witness would otherwise be unwilling or unable to attend a trial in person because of safety, health, or work-related concerns. ${ }^{7}$ In addition, although courts in the United States generally seem wary of allowing remote testimony in criminal trials, some have allowed adult witnesses to testify via two-way, live VCT under circumstances in which the witness would not otherwise be willing or able to appear at the trial because of safety or health concerns, or because they were beyond the court's subpoena power. ${ }^{8}$

4. See, e.g., Richard D. Friedman, Remote Testimony, 35 U. MicH. J.L. REFORM 695, 701-08 (2002) (discussing the Confrontation Clause implications of allowing remote witness testimony against defendants in criminal cases).

5. See, e.g., United States v. Bordeaux, 400 F.3d 548, 554 (8th Cir. 2005) (“The Constitution favors face-to-face confrontations to reduce the likelihood that a witness will lie.").

6. Fredric Lederer, The Legality and Practicality of Remote Witness Testimony, Prac. Litigator, Sept. 2009, at 19, 27 (noting the concern that remote testimony may impede the fact finder's ability to observe and determine the witness's demeanor).

7. See Riley A. Williams, Videoconferencing: Not a Foreign Language to International Courts, 7 OKLA. J.L. \& TECH. 54 (2011) ("Through videoconferencing, unavailable witnesses can be transmitted into courtrooms."); see also, e.g., INT'L CRIM. CT. R. P. \& EVID., available at http://www.icc-cpi.int/NR/rdonlyres/F1E0AC1C-A3F34A3C-B9A7-B3E8B115E886/140164/Rules_of_procedure_and_Evidence_English.pdf (providing in Rule 67 that the court may allow a witness to give audio or video testimony, provided the technology allows the witness to be examined by all parties at the time the witness testifies); SPECIAL CT. FOR SIERRA LEONE R. P. \& EVID., available at http://www.sc-sl.org/LinkClick.aspx?fileticket=yNjqn5TIYKs\%3d\&tabid=176 (providing in Rule 85D for video testimony at the order of the trial court); Int'l Tribunal for the Prosecution of Persons Responsible for Serious Violations of Int'l Humanitarian Law Committed in the Territory of the Former Yugoslavia Since 1991, Rules of Procedure and Evidence, U.N. Doc. IT/32 (Feb. 11, 1994) [hereinafter ICTY RPE], reprinted in 33 I.L.M. 484 (1994) (providing in Rule 81 bis that proceedings may be conducted by videoconference link if consistent with the interests of justice).

8. See, e.g., United States v. Gigante, 166 F.3d 75, 79-82 (2d Cir. 1999) (finding no Confrontation Clause violation where the trial court allowed a witness in an organized-crime case to testify from a remote location since the witness's health prevented him from traveling and the defendant's health also prevented him from traveling to a distant location to depose the witness); Harrell v. State, 709 So. 2d 1364, 1367-70 (Fla. 1998) (affirming decision to allow two Argentine nationals living in 
This Article proposes a rule for use in maritime piracy cases that would allow witnesses under some circumstances to testify remotely by way of two-way, live VCT so as to better facilitate the prosecution of those cases. Maritime piracy is the oldest crime over which states can exercise universal jurisdiction. ${ }^{9}$ Most states are also parties to the UN Convention on the Law of the Sea (UNCLOS), which codifies piracy's status as a universal-jurisdiction crime. ${ }^{10}$ Yet, even as pirate attacks continue to rise in number and severity, ${ }^{11}$ pirates face little risk that they will be prosecuted and punished for their crimes. Instead of prosecuting pirates, for the most part, the world community has been content to simply release them. ${ }^{12}$

One reason offered to explain this reluctance to prosecute focuses on the expense and difficulty of mounting cases of such international proportions and which involve evidence, suspects, victims, and witnesses from around the globe. ${ }^{13}$ If live witness testimony is

Argentina to testify remotely by live satellite video against the defendant in a case charging him with robbing the two Argentines while they were on vacation in Miami because, among other things, the witnesses lived beyond the subpoena power of the court).

9. See Miriam Cohen, The Analogy Between Piracy and Human Trafficking: A Theoretical Framework for the Application of Universal Jurisdiction, 16 BuFF. HuM. RTS. L. REV. 201, 201 (2010) (noting that the doctrine of universal jurisdiction was developed to address piracy that occurred on the high seas).

10. See United Nations Convention on the Law of the Sea, Dec. 10, 1982, 1833 U.N.T.S. 397 [hereinafter UNCLOS]; Chronological Lists of Ratifications of, Accessions and Successions to the Convention and the Related Agreements, UNITED NATIONS DIVISION FOR OCEAN AFF. \& L. SEA, http://www.un.org/Depts/los/reference_files/ chronological_lists_of_ratifications.htm (last updated Oct. 4, 2012). The United States is not a party to UNCLOS; however, it ratified an earlier version of the treaty with identical provisions regarding piracy. See Geneva Convention on the High Seas, Apr. 29, 1958, 13 U.S.T. 2312, 450 U.N.T.S. 82 (discussing and defining piracy).

11. According to the International Maritime Bureau (IMB), the number of reported yearly pirate attacks in 2011 was almost double the number reported in 2007, and most attacks now involve the use of weapons. See Int'l Chamber of Commerce International Maritime Bureau Rep, Jan. 1-Dec. 13, 2011, Piracy and Armed Robbery Against Ships, at 5, 10 (2011) [hereinafter ICC-IMB 2011 Report] (reporting 263 actual and attempted attacks in 2007 compared to 445 in 2011). The IMB includes in its annual report acts of piracy and acts of armed robbery against ships, as well as attempts of the same. The IMB's definition of piracy includes illegal acts of violence against a ship travelling on the high seas or any act of inciting the same. Id. at 3. Its definition of armed robbery against ships includes acts of violence-or any act of inciting an act of violence-against a ship located "within a State's internal waters, archipelagic waters and territorial sea." Id.

12. See, e.g., U.N. Special Adviser to the Secretary-General, Rep. of the Special Adviser to the Secretary-General on Legal Issues Related to Piracy off the Coast of Somalia, I 43, U.N. Doc. S/2011/30 (Jan. 24, 2011) (by Jack Lang) [hereinafter Lang] (reporting that nine out of ten pirates captured by the world's navies are not prosecuted).

13. See James Kraska, Coalition Strategy and the Pirates of the Gulf of Aden and the Red Sea, 28 COMP. STRATEgy 197, 207 (2009) (describing the logistical 
required, those expenses can be particularly substantial since the state would have to pay the costs of transporting witnesses who reside in different parts of the world to the trial. Obtaining live testimony is not only difficult from a cost perspective, however. States may not be able to compel nonnationals to attend a trial in person. States also may not be able to entice witnesses to attend if they are ill, working at sea, or concerned for their safety-which can be the case with crew members who have survived an attack or naval officers who have assisted in capturing pirates during an attack. Indeed, in his January 2011 report, the Special Adviser to the Secretary-General on Legal Issues Related to Piracy off the Horn of Africa, Mr. Jack Lang, noted that the requirement of in-person testimony was proving to be an obstacle to swift trials "either because the victims do not wish to go to lengths to give evidence, are afraid, or their employers may not allow them to testify."14

Allowing the state to produce some witnesses remotely under certain circumstances can alleviate some of the difficulties of obtaining the evidence necessary to successfully prosecute maritime pirates while at the same time furthering the interests of justice. This Article proposes that courts allow prosecution witnesses to testify by two-way, live VCT in maritime cases on a case-by-case basis in the interests of justice, upon proof by the requesting party that (1) the testimony is necessary to the fair and just resolution of the case, (2) the witness is unable or unwilling for good reason to travel to the court to testify in person, and (3) the transmission will use appropriate safeguards to protect the defendant's rights to a fair trial and to ensure that the witness understands the obligation to testify truthfully. This test balances the interests of the various parties to the proceeding and also ensures that the trial can proceed with the evidence needed to resolve criminal matters fairly, justly, and expeditiously. The state would not lose valuable witness testimony; would not have to pay great sums for witness travel; and could try cases more swiftly, without the need to accommodate witness travel schedules. Witnesses would be spared the inconvenience of traveling great distances, at a cost to their health, safety, or job security. Defendants' rights to a fair trial are also protected when witnesses testify remotely using two-way, live VCT: witnesses will have to confront defendants with their testimony; defendants and witnesses will be able to view each other; the defendant will be able to subject witnesses to contemporaneous cross-examination during the trial; and the court and any jury will still be able to see the witness, hear

difficulties associated with prosecuting pirates because the cases can involve ships, cargo, victims, witnesses, and suspects from a host of different countries).

14. Lang, supra note 12 , ๆ 61. 
the testimony, and assess witness credibility. Defendants can even benefit from a rule that allows some witnesses to testify remotely because trials can proceed and be resolved more swiftly without requiring defendants to linger in custody awaiting their day in court. While it need not become the norm, allowing witnesses to testify remotely in maritime piracy trials under some circumstances would further the interests of justice and also prompt more states to embrace their duty to prosecute pirates instead of simply releasing them.

Part II of this Article discusses the technology of two-way, live VCT and some of its perceived advantages and disadvantages. Part III examines several approaches used to analyze the issue of whether to admit two-way, live VCT witness testimony against defendants in criminal cases. Specifically, this Part examines the rules and decisions of various international criminal courts, focusing on their reasons for allowing or denying remote prosecution-witness testimony in particular circumstances. With that same focus, this Part also examines the law in the federal courts of the United States as it relates to remote prosecution-witness testimony in criminal trials. Part IV follows with a description of the modern piracy problem, the international law governing the crime of maritime piracy, and the need to further encourage states to use the available laws to prosecute pirates, instead of releasing them and allowing them to continue their illegal activities. In Part V, this Article discusses the proposed rule for allowing prosecution witnesses to testify remotely in maritime piracy trials by way of two-way, live VCT under some circumstances in the interest of justice.

\section{Two-WAy, LiVe Videoconferencing TEChNOLOGy (VCT)}

Two-way, live VCT permits witnesses to testify remotely in courtrooms around the world from any location, as long as both locations are equipped with the necessary technology. That technology relies on point-to-point data connections between locations, which must house a camera, a microphone, screens to display visual images, and the videoconferencing hardware (the "codec"). ${ }^{15}$ In order to transmit images and sound, the equipment on

15. See Lederer, supra note 6, at 20 (describing the required equipment for standard videoconferencing). Professor Frederic Lederer is Chancellor Professor of Law and Director of the Center for Legal and Court Technology at the William and Mary Law School. For many years, he has been involved with the law school's hightechnology courtroom, the McGlothlin Courtroom. Fredric Lederer, WILLIAM \& MARY L. SCH., http://web.wm.edu/law/faculty/bios/fulltime/lederer-46.php?svr=law (last visited Oct. 20, 2012). 
each end must be connected to an Integrated Services Digital Network (ISDN), which relies on something similar to highbandwidth telephone lines, or an Internet Protocol (IP). ${ }^{16}$ Two-way, live VCT transmits high-quality video images that are fully synchronized with audio from one location to the other simultaneously. ${ }^{17}$

Most videoconferencing today is increasingly delivered via the IP mode and it can be effectively free as long as the court or other location has an internet connection. ${ }^{18}$ "ISDN-based videoconferencing requires specialized communications lines" and will require a per-call charge in addition to any monthly subscription cost for the line. ${ }^{19}$ While both methods can produce clear images and voice-especially when using newly available high-definition technology-the IP-based method can potentially encounter some interference if bandwidth is being used by others during the witness's remote testimony. ISDNbased methods will be more reliable in this regard, but more expensive. ${ }^{20}$

Worth noting is that the technology is ever-improving and becoming increasingly affordable. ${ }^{21}$ The ability to produce videoconferencing images in high definition is one recent innovation mentioned above. Other innovations include the ability to concurrently transmit digital documents on one screen while the video image is being displayed on another. ${ }^{22}$ Also, while videoconferencing systems have typically used flat-panel televisions to display content, some manufacturers have developed desktop monitors with high-definition features. ${ }^{23}$ More sophisticated systems include remote controls to allow "zooming" or "panning" functionality and some have screen options that allow the display of multiple views of the courtroom or participants. ${ }^{24}$ Quite recent features of newer VCT systems use cameras that will track courtroom participants wearing a unique "badge" that signals the camera to follow their movements. ${ }^{25}$

\footnotetext{
16. Lederer, supra note 6, at 20.

17. Id.

18. Id. at 21

19. Id.

20. See id. ("ISDN tends to give a more dependable connection but is being increasingly abandoned in favor of the less expensive IP method of connection.").

21. See Williams, supra note 7 , at 1 (discussing evolving technology in the courtroom).

22. See Lederer, supra note 6, at 20 ("High-end videoconferencing equipment permits the concurrent transmission of computer images.").

23. See id. at 21 (describing the various types of monitors used in courtrooms).

24. See Williams, supra note 7 , at 3 (noting various aspects of advanced videoconferencing systems).

25. See id. (discussing the features and functionality of the "badges").
} 
Experiments with VCT remote witness testimony at William and Mary Law School's high-technology McGlothlin Courtroom, moreover, indicate that while the technology cannot exactly replicate the situation of live, face-to-face witness testimony in the courtroom, it can come quite close. In that courtroom, the technology can display a witness's image directly behind the witness stand, a judge's image directly behind the bench, and counsels' images at counsel tables. That technology also permits remote witnesses to see different views of the courtroom and speakers. ${ }^{26}$ Furthermore, the results of some controlled experiments and anecdotal evidence indicate that jurors tend to perceive remote witnesses very similarly to how they perceive witnesses who testify live in the courtroom. ${ }^{27}$ Indeed, Professor Fredric Lederer suggests that as the technology continues to improve, image and voice quality may become so good that one may have difficulty observing that a remote witness is not physically present. ${ }^{28}$

Judges also seem to be increasingly comfortable using VCT in a variety of proceedings that previously would have required all participants to appear together in the same room. International criminal tribunals, especially the International Criminal Tribunal for the former Yugoslavia (ICTY), have successfully used VCT for remote witness testimony. ${ }^{29}$ Australia, Canada, the United Kingdom, and Singapore all permit remote VCT witness testimony in some circumstances. ${ }^{30}$ In the United States, Federal Rule of Civil Procedure 43(a) authorizes using remote witness testimony during

26. See Lederer, Courtroom Technology, supra note 1, at 908 (noting the ability of a remote witness to see either a single camera image or multiple images of William and Mary Law School's McGlothlin Courtroom).

27. See id. ("[R]emote appearances appear to be treated by the courtroom participants just as if those persons were physically in the courtroom.”).

28. Lederer, supra note 6, at 29.

29. See, e.g., Sanja Kutnjak Ivkovic, Justice by the International Criminal Tribunal for the Former Yugoslavia, 37 STAN. J. INT'L L. 255, 286 (2001) (noting that the ICTY allowed eleven witnesses in the Prosecutor $v$. Tadic case to testify remotely from a location in the former Yugoslavia); see also Williams, supra note 7, at 11-13 (discussing the standards for using remote witness testimony in the ICTY and International Criminal Tribunal for Rwanda (ICTR)).

30. See Jeremy Barnett, The United Kingdom, 12 WM. \& MARY BILL RTS. J. 687, 690 (2004) (stating that courts in the United Kingdom use VCT to allow child and foreign witnesses to testify in certain kinds of criminal cases); Julian Borkowski, Court Technology in Canada, 12 WM. \& MARY BILL RTS. J. 681, 682 (2004) (reporting that in Canada, courts use VCT in various civil and criminal matters); Ros Macdonald \& Anne Wallace, Review of the Extent of Courtroom Technology in Australia, 12 WM. \& MARY BILL RTS. J. 649, 650 (2004) (stating that courts in Australia began using VCT to allow vulnerable witnesses to testify in remote locations removed from the courtroom); Richard Magnus, The Confluence of Law and Policy in Leveraging Technology: Singapore Judiciary's Experience, 12 WM. \& MARY BILL RTS. J. 661, 663-64 (2004) (explaining that VCT is used in many types of court proceedings in Singapore, such as bail hearings, pretrial conferences, civil trials, and criminal trials, for specified offenses to allow vulnerable witnesses to testify remotely). 
civil trials "in compelling circumstances and with appropriate safeguards." ${ }_{11}$ Federal appellate court judges have used VCT to conduct oral arguments. ${ }^{32}$

Of course, even if many courts are comfortable using VCT and conclude that its use is practical and proper in certain instances, it does not necessarily follow that remote prosecution-witness testimony should become the norm in criminal cases in the United States or elsewhere. Criminal cases are a unique category of proceedings that can result in a defendant losing his freedom if convicted. Thus, commentators and courts are right to advocate that limitations be placed on the ability to use remote prosecution-witness testimony. They are also right to advocate that the remote experience be as similar as possible to the live experience for both the witness and the individuals in the courtroom. With these concerns in mind, Part III below discusses some approaches used by various international criminal courts and by federal courts in the United States to analyze the question of when to admit two-way, live VCT witness testimony against defendants in criminal cases.

\section{SOME APPROACHEs UsED To ANALYZE When to Allow Prosecution Witnesses to Testify By Two-Way, Live VCT in CRIMINAL TRIALS}

\section{A. Remote VCT Prosecution Testimony in International Criminal Courts}

The international criminal courts generally seem to look favorably on the use of two-way, live VCT prosecution witness testimony, at least under some circumstances in which witnesses with necessary or useful evidence would otherwise be unable or unwilling to testify in person. For example, the ICTY, the Special Court for Sierra Leone (SCSL), and the International Criminal Court (ICC) all have procedural rules permitting witnesses to testify remotely in certain situations. ${ }^{33}$ Although the International Criminal Tribunal for Rwanda (ICTR) has no specific procedural rule

31. FED. R. Civ. P. 43(a).

32. See Advantages of Videoconferencing Grow with Use, U.S. CTS. (Aug. 2006) http://www.uscourts.gov/news/TheThirdBranch/06-08-01/Advantages_of_

Videoconferencing_Grow_with_Use.aspx (describing a recent Federal Judicial Center report surveying appellate court judges and their use of videoconferencing).

33. See supra note 7 and accompanying text. Rule 81 bis was adopted to replace Rule 71 bis on July 12, 2007, to allow for greater use of testimony by VCT. See Rules of Procedure and Evidence of the International Criminal Tribunal for the Former Yugoslavia, UN ICTY, http://www.icty.org/sections/LegalLibrary/RulesofProcedureandEvidence (last visited Oct. 20, 2012). 
addressing VCT witness testimony, the tribunal has granted some requests to allow witnesses to testify remotely when "necessary to safeguard the witness's security' or in the interest of justice."34

\section{The International Criminal Tribunal for the Former Yugoslavia $^{35}$}

The ICTY allows remote testimony pursuant to Rule 81 bis of its Rules of Procedure and Evidence if such testimony is consistent with the interests of justice. ${ }^{36}$ Although Rule 81 bis itself does not define the interests of justice, a review of the Tribunal's decisions provides guidance on what is required to satisfy that standard. Specifically, the ICTY will only allow VCT witness testimony when the moving party shows that (1) "the witness is unable, or has good reasons to be unwilling," to come to the court; (2) the testimony is "sufficiently important to make it unfair to the requesting party to proceed without it"; and (3) the accused will "not be prejudiced in the exercise of his or her right to confront the witness." 37 Thus, the ICTY interests of justice test balances the witness's needs with those of the parties to the trial process: it ensures the parties can present the evidence

34. Prosecutor v. Nizeyimana, Case No. ICTR-00-55C-T, Decision on Prosecutor's Extremely Urgent Motion for Testimony via Video-Link, 15 (Feb. 14, 2011).

35. In 1993, the United Nations established the International Tribunal for the Prosecution of Persons Responsible for Serious Violations of International Humanitarian Law Committed in the Territory of the Former Yugoslavia Since 1991 to preside over trials against those who had committed atrocities and crimes against humanity during the armed conflict in the Balkans. See generally PAUL R. WILLIAMS \& Michael P. SCHARF, PeACE With Justice?: WAR CRIMES AND ACCOUNTABILITY IN THE Former YugOSLAVIA 98-101 (2002) ("[I]n February 1993, the War Crimes Commission joined a growing international chorus publicly calling for the creation of a Nuremberglike tribunal to try persons believed to be responsible for atrocities in the former Yugoslavia.").

36. ICTY RPE, supra note 7.

37. See, e.g., Prosecutor v. Karadžić, Case No. IT-95-5/18-T, Decision on Prosecution's Motion for Testimony To Be Heard via Video-Conference Link, ๆ ๆ 5-6 (Int'l Crim. Trib. for the Former Yugoslavia June 17, 2010); Prosecutor v. Stanišić, Case No. IT-03-69-T, Decision on Prosecution Motions To Hear Witnesses by VideoConference Link, If 8 (Int'l Crim. Trib. for the Former Yugoslavia Feb. 24, 2010); Prosecutor v. Gotovina, Case No. IT-06-90-T, Reasons for Decision Granting Prosecution's Motion To Cross-Examine Four Proposed Rule 92 bis Witnesses and Reasons for Decision To Hear the Evidence of Those Witnesses via Video-Conference Link, If 7 (Int'l Crim. Trib. for the Former Yugoslavia Nov. 3, 2009); see also Prosecutor v. Tadíc, Case No. IT-94-1-T, Decision on the Defence Motions To Summon and Protect Defence Witnesses, and on the Giving of Evidence by Video-Link, I 19 (Int'l Crim. Trib. for the Former Yugoslavia June 25, 1996) (describing the standard for VCT witness testimony that preceded the adoption of a formal rule: namely, that the witness's testimony is so important that it would be unfair to proceed without it and that the witness is unable or unwilling to come to the Tribunal to testify). 
required to show the guilt or innocence of the defendant, while at the same time protecting the defendant's interest in being able to examine the witnesses against him.

As to the first criterion, the ICTY has concluded that concerns related to the witness's health and safety may satisfy the requirement that the witness be unable or unwilling for good reason to testify in person. For example, in Prosecutor v. Stanišić, the Tribunal decided the prosecutor had sufficiently established that one witness was unable to travel to the Hague based on a doctor's report showing the poor state of the witness's health. ${ }^{38}$ It further concluded that two other prosecution witnesses had "good reasons to be unwilling to travel" due to their advanced age since both were over seventy-five years old. ${ }^{39}$ In Prosecutor $v$. Tadic, the Tribunal found that defense counsel had met its burden of demonstrating that certain witnesses were sufficiently unwilling to attend the trial in the Hague because they feared arrest by the prosecution. ${ }^{40}$ In Prosecutor $v$. Gotovina, there was no specific information showing that several witnesses were unable or unwilling to travel to the Hague. ${ }^{41}$ Nevertheless, the Tribunal concluded that ordering the witnesses to be cross-examined by video link, rather than in person, was consistent with the interests of justice because the witnesses' combined testimonies would take no more than one court day and because of the need to expeditiously conclude the trial. ${ }^{42}$

Regarding the third criterion of the ICTY's interests-of-justice test, ICTY decisions emphasize the similarities between remote and live testimony and generally decline to find that remote testimony would violate the defendant's rights to confront and cross-examine witnesses. ${ }^{43}$ In fact, in Gotovina, the Tribunal explained as follows:

38. Stanišić, Case No. IT-03-69-T, Decision on Prosecution Motions To Hear Witnesses by Video-Conference Link, ๆ $12-14$.

39. Id.

40. Tadic, Case No. IT-94-1-T, Decision on the Defence Motions To Summon and Protect Defence Witnesses, and on the Giving of Evidence by Video-Link, 19.

41. Gotovina, Case No. IT-06-90-T, Reasons for Decision Granting Prosecution's Motion To Cross-Examine Four Proposed Rule 92 bis Witnesses and Reasons for Decision To Hear the Evidence of Those Witnesses via Video-Conference Link, \ 12.

42. Id. The Tribunal noted that although three criteria guide the decision on whether to permit remote witness testimony, the ultimate determination is whether permitting VCT testimony "would be consistent with the interests of justice." Id. ๆ 7.

43. According to Article 21(4)(e) of the ICTY Statute, a defendant has the right "to examine, or have examined, the witnesses against him and to obtain the attendance and examination of witnesses on his behalf under the same conditions as witnesses against him." Int'l Tribunal for the Prosecution of Persons Responsible for Serious Violations of Int'l Humanitarian Law Committed in the Territory of the Former Yugoslavia Since 1991, Updated Statute of the International Criminal Tribunal for the Former Yugoslavia (Sept. 2009), http://www.icty.org/x/file/Legal\%20Library/Statute/ statute_sept09_en.pdf. 
According to the jurisprudence of the Tribunal, video conferencing is an extension of the Trial Chamber to the location of the witness that neither denies the accused his or her right to confront the witness, nor causes him or her material prejudice by the physical absence of the witness. Video conferencing therefore respects the right of the accused to cross-examine and directly confront witnesses while observing their reactions, and allows the Chamber to assess the credibility and reliability of the testimony in the same manner as for a witness in the courtroom. Testimony by video-conference link should be given as much probative value as testimony presented in the courtroom. ${ }^{\mathbf{4 4}}$

Even when the ICTY determines that allowing remote witness testimony is in the interests of justice, however, the Tribunal has emphasized the need for safeguards to ensure that the remote testimony is as similar as possible to live, in-person testimony. In its Tadic decision, for example, the Tribunal suggested implementing the following guidelines for the orderly conduct of video-link testimony. First, the testimony should be given in an appropriate venue, such as a courtroom or embassy, where the witness would be encouraged to give truthful and open testimony and where "the safety and solemnity of the proceedings" can be guaranteed. ${ }^{45}$ In addition, a "Presiding Officer" should be present to oversee the proceedings, administer an oath so that witnesses understand their obligation to speak truthfully or face prosecution for perjury, and ensure that testimony is given freely and voluntarily. ${ }^{46}$ Finally, the technology must incorporate monitors that allow witnesses to view "the Judges, the accused, and the questioner," and vice versa. ${ }^{47}$

44. Gotovina, Case No. IT-06-90-T, Reasons for Decision Granting Prosecution's Motion To Cross-Examine Four Proposed Rule 92 bis Witnesses and Reasons for Decision To Hear the Evidence of Those Witnesses via Video-Conference Link, I 8; see also, e.g., Prosecutor v. Karadžić, Case No. IT-95-5/18-T, Decision on Prosecution's Motion for Testimony To Be Heard via Video-Conference Link, I 9 (Int'l Crim. Trib. for the Former Yugoslavia June 17, 2010) (agreeing that the use of videoconference link would not violate the accused's right to confront the witness); Prosecutor v. Milutinović, IT-05-87, Decision on Prosecution Motion for Testimony of K58 To Be Heard via Video Link Conference, I 2 (Int'l Crim. Trib. for the Former Yugoslavia Nov. 1, 2006) (granting a motion for video-link testimony with the same reasoning as the Gotovina court). It bears noting that in its first case considering the possibility of remote witness testimony in 1996, the Tribunal initially suggested that the "evidentiary value of testimony provided by video-link, although weightier than that of testimony given by deposition, is not as weighty as testimony given in the courtroom." Tadic, Case No. IT-94-1-T, Decision on the Defence Motions To Summon and Protect Defence Witnesses, and on the Giving of Evidence by Video-Link, 121.

45. Tadic, Case No. IT-94-1-T, Decision on the Defence Motions To Summon and Protect Defence Witnesses, and on the Giving of Evidence by Video-Link, $₫ 22$.

46. Id.

47. Id. 
2. The International Criminal Tribunal for Rwanda ${ }^{48}$

The ICTR also allows witnesses to testify remotely under some circumstances that similarly balance the interests of the various parties to the proceeding. Although Rule 90(A) of the ICTR's Rules of Procedure and Evidence ${ }^{49}$ states that witnesses should testify in person at the court, the ICTR permits remote VCT witness testimony when '"necessary to safeguard the witness's security' or in the interest of justice." 50 In determining whether VCT witness testimony is in the interests of justice, the ICTR considers: (1) "the importance of [the witness's] testimony," (2) "the witness's inability or unwillingness to attend," and (3) "whether a good reason has been adduced for that inability or unwillingness." 51 The party seeking provision for remote witness testimony bears the burden of demonstrating "that the witness has a credible basis for refusal, and that those grounds are genuinely held, giving a Chamber reason to believe that he or she will not testify unless a Chamber allows the witness to do so via video-link." 52 When ruling on a request for testimony by VCT, the ICTR will also consider the rights of the parties to the proceeding "by ensuring in particular that the witness's appearance on a video screen instead of his/her physical presence in the courtroom does not reduce the parties' ability to evaluate his/her testimony and to cross-examine him/her."53

On the question of what constitutes a valid reason for a witness to be deemed genuinely unable or unwilling to testify in person, it

48. The United Nations established the ICTR in 1994 to preside over crimes committed during the civil war in Rwanda. See generally VIRGINIA MORRIS \& MICHAEL P. SCHARF, THE INTERNATIONAL CRIMINAL TRIBUNAL FOR RWANDA (1998) (providing an in-depth account of the creation of the Tribunal and its governing rules and statute).

49. Rule 90(A) of the ICTR Rules of Procedure and Evidence states that "[w]itnesses shall, in principle, be heard directly by Chambers." Rules of Procedure and Evidence of the International Criminal Tribunal for Rwanda, Rule 90(A), U.N. Doc. ITR/3/REV.1 (June 29, 1995).

50. Prosecutor v. Nizeyimana, Case No. ICTR-00-55C-T, Decision on Prosecutor's Extremely Urgent Motion for Testimony via Video-Link, If 5 (Feb. 14, 2011) (quoting Prosecutor v. Bagosora, Case No. ICTR-98-41-T, Decision on the Prosecution Request for Testimony of Witness BT via Video-Link (TC), I 8 (Oct. 8, 2004)).

51. Id. ๆ 6.

52. Id.

53. Prosecution v. Muvunyi, Case No. ICTR-2000-55A-PT, Decision on Prosecution's Motion To Have Prosecution Witness NN Testify by Video-Link, $\mid 2$ (Dec. 30, 2008). Like the ICTY Statute, the Statute for the ICTR provides that an accused has the right " $\mathrm{t}$ ]o examine, or have examined, the witnesses against him or her and to obtain the attendance and examination of witnesses on his or her behalf under the same conditions as witnesses against him or her." Statute of the International Criminal Tribunal for Rwanda art. 20(4)(e), Nov. 8, 1994, 33 I.L.M. 1598, available at http://www.unictr.org/Portals/0/English/Legal/Statute/2010.pdf. 
appears that health, safety, and work-related travel concerns can all be sufficient in some instances. In Prosecutor $v$. Rukundo, the Tribunal allowed a witness to testify remotely for the prosecution because medical documentation demonstrated that he was too ill to travel from Rwanda to Arusha. ${ }^{54}$ It also permitted another witness in the case to testify by video when affidavit evidence showed the witness had been victimized in Rwanda after previously testifying before the Tribunal and feared similar reprisals should he be seen leaving Rwanda to testify again. ${ }^{55}$ Indeed, in that case, the ICTR also rejected the defense's request to require the parties to travel to Rwanda to hear the witnesses testify in person, stating:

\footnotetext{
The Chamber is not convinced that such a course of action is necessary in order to safeguard the right of the Accused to confront witnesses against him, or for the preparation of cross-examination. In the Chamber's view the right of the Accused to a fair trial will be adequately preserved by allowing each of the Parties to send a representative to the venue of the video-link proceedings to look after their respective interests. However, all the examinations of the witness will be conducted from the courtroom in Arusha. 56
}

Regarding work-related travel concerns, in Prosecutor $v$. Nchamihigo, the ICTR concluded that the prosecution had met its burden of showing a witness was unable or unwilling to testify in person when the evidence showed the witness was under travel restrictions imposed by his employer. ${ }^{57}$ The Tribunal explained that the prosecution had attempted to negotiate the witness's release from his employer, but that the employer had continued to refuse. ${ }^{58} \mathrm{In}$ such circumstances, allowing the witness to testify remotely furthered the "interest of justice" standard. ${ }^{59}$ Conversely, the ICTR decided there was no credible basis for a witness's refusal to testify when the witness claimed in only vague terms and only one week before he was scheduled to testify that he feared he would lose his job or face harassment at work if he were required to appear in person at the Tribunal. ${ }^{60}$

54. Prosecutor v. Rukundo, Case No. ICTR-2001-70-PT, Decision on the Prosecutor's Urgent Motion for Witnesses BPA and BLR To Give Testimony via VideoLink, ๆ 13 (Mar. 1, 2007).

55. Id. $\mid$ ฯ 5,14 .

56. Id. $₫ 15$.

57. Prosecutor v. Nchamihigo, Case No. ICTR-2001-63-T, Decision on the Prosecution Motion To Hear the Testimony of Witness LM by Video-Link, ๆ $5-6$ (Jan. $25,2007)$.

58. Id. $\quad$ 『 6.

59. Id. \7.

60. See Prosecutor v. Nizeyimana, Case No. ICTR-00-55C-T, Decision on Prosecutor's Extremely Urgent Motion for Testimony via Video-Link, 9 ฯ 1, 8 (Feb. 14, 2011) (emphasizing that the defendant's fear of losing employment is not a credible basis for a refusal to testify). 
In sum, the ICTR has concluded in various situations that allowing some witnesses to testify remotely would further the interests of justice and also properly balance the interests of the various parties to the proceeding, while still ensuring a fair trial. However, the ICTR has also emphasized that "[h]earing testimony via video-link is an exceptional measure, granted only upon sound and legitimate justification based on proper documentation." 61 Moreover, a review of the Tribunal's jurisprudence indicates that not all judges are convinced that testimony by VCT truly and fully replicates the experience of live, in-person witness testimony. In a 2006 decision, one chamber of the ICTR expressed concerns about the Tribunal's ability to assess the demeanor of a particularly important prosecution witness should that witness testify remotely. ${ }^{62}$ In considering a prosecution motion urging a reconsideration of the chamber's decision denying the request to allow that witness to testify by VCT, the chamber explained that although it agreed the prosecution had shown that the witness had reasons to fear for his safety should he testify in person, it was also satisfied that the ICTR could provide heightened security measures sufficient to ensure the witness's safety in Arusha. ${ }^{63}$ In a subsequent case, Prosecutor $v$. Nizeyimana, the ICTR again emphasized the ability of the court in Arusha to safeguard witnesses to allow for testimony in person. ${ }^{64}$ The Tribunal noted that it was willing to accommodate witnesses who fear for their safety, but that those witnesses would only be able to testify remotely upon affidavit evidence clearly stating the precise nature of their fears and when it found there were no other appropriate methods to ensure the witness's safety in Arusha. ${ }^{65}$

61. Prosecutor v. Ndahimana, Case No. ICTR-2001-68-T, Decision on Defence Motion To Hear the Testimony of Witnesses BX7 and FB1 via Video Link, I 16 (Feb. $25,2011)$.

62. Prosecutor v. Zigranyirazo, Case No. ICTR-2001-73-T, Decision on the Prosecution Joint Motion for Re-Opening Its Case and for Reconsideration of the 31 January 2006 Decision on the Hearing of Witness Michel Bagaragaza via Video-Link, ๆ 22 (Nov. 16, 2006)

63. Id. ๆ 24.

64. See Nizeyimana, Case No. ICTR-00-55C-T, Decision on Prosecutor's Extremely Urgent Motion for Testimony via Video-Link, If 5 (stating that, while witnesses should generally appear in person, testimony in lieu of physical appearance may be used "when necessary to safeguard the witness's security" (quoting Prosecutor v. Bagosora, Case No. ICTR-98-41-T, Decision on the Prosecution Request for Testimony of Witness BT via Video-Link (TC), 8 (Oct. 8, 2004)).

65. See id. (stating that the burden of proof rests with the party making the request to show the grounds of the witness's fear and that the witness would not testify other than by video-link). 


\section{The Special Court for Sierra Leone ${ }^{66}$}

According to Rule 85(D) of the Rules of Procedure and Evidence of the SCSL, "[e]vidence may be given directly in court, or via such communications media, including video, closed-circuit television, as the Trial Chamber may order." 67 Decisions of the SCSL provide guidance on when remote video testimony is proper under Rule 85(D). Similar to the ICTY and ICTR, the SCSL allows remote testimony by VCT only when it would further the interests of justice and after considering the particular circumstances making the witness unable to travel to the court.68 Indeed, in Prosecutor v. Taylor, the court rejected the prosecution's request for a rule allowing parties to present witness testimony by VCT as a general matter unless the party opposing the request showed good cause as to why denying the remote method of testimony existed for a particular witness. ${ }^{69}$ Rather, the court noted that although Rule 85(D) imposes no conditions on the use of video testimony, it and other rules of the court demonstrate a general preference for witnesses to give evidence directly in the presence of the court. ${ }^{70}$ Even though the rules also do not require "a face to face" confrontation between the accused and every individual, the court emphasized that it must make decisions about the conduct of the trial that further the "interests of justice,"

66. The SCSL was established by agreement between the United Nations and the Government for Sierra Leone in August 2000. The SCSL has the power to prosecute persons who are most responsible for serious violations of international humanitarian and Sierra Leone law committed in Sierra Leone since 1996. Statute of the Special Court for Sierra Leone art. 1, Aug. 14, 2000, 2178 U.N.T.S. 138 [hereinafter SCSL Statute], available at http://www.sc-sl.org/LinkClick.aspx?fileticket=uClnd1M JeEw\%3d\&tabid=176.

67. Special CT. FOR Sierra LeOne R. P. \& Evid., available at http://www.scsl.org/LinkClick.aspx?fileticket=yNjqn5TIYKs\%3d\&tabid=176.

68. See, e.g., Prosecutor v. Taylor, Case No. SCSL-03-1-T, Decision on Public Prosecution Motion To Allow Witness TF1-303 To Give Testimony by Video-Link (Nov. 18,2008 ) (granting prosecution's unopposed motion to permit remote testimony where witness recently gave birth); Prosecutor v. Taylor, Case No. SCSL-03-01-PT-217, Decision on Prosecution Motion To Allow Witnesses To Give Testimony by Video-Link), ๆ $25-27$ (Mar. 30, 2007), http://www.sc-sl.org/Documents/SCSL-03-01-PT-217.pdf (denying prosecution motion for a general order allowing parties to present testimony remotely unless the opposing party shows good cause to deny this method of receiving testimony by particular witnesses).

69. Taylor, Case No. SCSL-03-01-PT-217, Decision on Prosecution Motion To Allow Witnesses To Give Testimony by Video-Link, ๆ $25-27$.

70. Id. \ๆ 22-24. The SCSL does not grant the accused a right to confront or be confronted by the witnesses against him. However, pursuant to Article $17 \S(4)(\mathrm{e})$ of the Statute of the Special Court for Sierra Leone, among the rights guaranteed to an accused is the right "[t]o examine, or have examined, the witnesses against him or her and to obtain the attendance and examination of witnesses on his or her behalf under the same conditions as witnesses against him or her." SCSL Statute, supra note 66. 
and not for "no reason at all."71 The court concluded that any decisions to exercise its discretion to permit remote VCT witness testimony would take into account the interests of justice, would be considered on a case-by-case basis, and would address the particular circumstances making the witness unable to come to the court. ${ }^{\mathbf{7 2}}$

Like the ICTY, the SCSL has also required that some safeguards be implemented so that remote witness testimony resembles inperson courtroom testimony as much as possible. The court has required witnesses to testify from a courtroom where the "safety and solemnity of the proceedings" can be guaranteed. ${ }^{73}$ It has also required the presence of a "Courtroom Officer" to oversee the proceedings, to inform witnesses of their duty to testify truthfully or be subject to a prosecution for perjury, and to "ensure that the testimony is given freely and voluntarily." 74 In addition, the court has permitted the parties to have a representative in the remote location to monitor the proceedings. ${ }^{75}$ Finally, as to the adequacy of the technology, the SCSL requires that witnesses be able to view "the Judges, the Accused and the questioner" from a monitor. ${ }^{76}$

\section{The International Criminal Court ${ }^{77}$}

Under Rule 67 of the ICC's Rules of Procedure and Evidence, the ICC may permit a witness to testify remotely by audio or video provided that (1) the technology permits the witness to be examined by all parties at the time of the witness's testimony and (2) the trial chamber ensures the "venue chosen for the conduct of the audio or video-link testimony is conducive to the giving of truthful and open testimony and to the safety, physical and psychological well-being,

71. Taylor, Case No. SCSL-03-01-PT-217, Decision on Prosecution Motion To Allow Witnesses To Give Testimony by Video-Link, ๆๆ 25-26.

72. Id. I 26.

73. Taylor, Case No. SCSL-03-1-T, Decision on Public Prosecution Motion To Allow Witness TF1-303 To Give Testimony by Video-Link, 3.

74. Id.

75. $I d$.

76. Id.

77. The ICC came into existence in July 2002 after the required sixty states had ratified the Rome Statute creating the court. The ICC is the first permanent, treaty-based international criminal court. States that have ratified the treaty creating the ICC agree that investigations may be commenced against the state's own nationals for the covered crimes of genocide, crimes against humanity, or war crimes, as long as those crimes were committed after the court came into existence or after the state ratified the treaty, whichever is later. Rome Statute of the International Criminal Court art. 11, July 17, 1998, 2187 U.N.T.S. 3, 91 [hereinafter Rome Statute]. 
dignity and privacy of the witness." 78 The limited case law interpreting and applying Rule 67 in the ICC's relatively brief existence suggests that the court views it as broadly authorizing remote witness testimony. While recognizing the presumption that witnesses will ordinarily testify live ${ }^{79}$ the court has stated that it will authorize the use of audio or video-link testimony when necessary, so long as the venue for the testimony would be conducive to "the giving of truthful and open testimony and to the safety, physical and psychological well-being, dignity and privacy of the witness." 80 It has also emphasized that it is not required to limit applications for remote video testimony to only those situations in which witnesses were unwilling or unable to attend court proceedings for medical or other reasons. ${ }^{81}$ Rather, "subject to the fundamental dictates of a fair trial," the ICC may consider a wide variety of factors in determining whether under the circumstances of the particular case a witness should be permitted to testify remotely using VCT. ${ }^{82}$

78. INT'L CRIM. CT. R. P. \& EVID., available at http://www.icc-cpi.int/NR/ rdonlyres/F1E0AC1C-A3F3-4A3C-B9A7-B3E8B115E886/140164/Rules_of_procedure_ and_Evidence_English.pdf.

79. See Rome Statute, supra note 77, art. 69(2) (providing that witness testimony shall be given in person unless provided by Article 68 or other rules). Whether the ICC can actually require witnesses to travel to the Hague to testify in person, however, is another matter. Article 64(6)(b) of the Rome Statute empowers the court to "[r]equire the attendance and testimony of witnesses," but Article 93(1)(e) imposes upon States Party only the duty to facilitate the voluntary appearance of individuals to appear as witnesses. See Claus Kress, The Procedural Law of the International Criminal Court in Outline: Anatomy of a Unique Compromise, 1 J. INT'L CRIM. JUST. 603, 616 (2003) (noting the apparent inconsistency between the two articles).

80. Prosecutor v. Lubanga Dyilo, Case No. ICC-01/04-01/06, Decision on Various Issues Related to Witnesses' Testimony During Trial, I 41 (Jan. 29, 2008) (citing INT'L CRIM. CT. R. P. \& EVID. 67(3)). The court further explained that it would make decisions about allowing such remote testimony "on a case-by-case basis, taking into account the views and concerns of the witness, the parties and, where relevant, the participants." Id.

81. See Prosecutor v. Lubanga Dyilo, Case No. ICC-01/04/01-06, Redacted Decision on the Defence Request for a Witness To Give Evidence via Video-Link, I I 3, 15-16 (Feb. 9, 2010) (granting defense's request to permit adult witness to testify remotely where witness lived in conditions of extreme poverty, had never used many modern conveniences, had no passport, and would have been extremely vulnerable and uncomfortable if she had to leave the general area where she currently resided); see also Prosecutor v. Bemba Gombo, Case No. ICC-01/05-01/08-947, Redacted Decision on the "Request for the Conduct of the Testimony of Witness CAR-OTP-WWWW-0108 by Video-Link," II 5-15 (Oct. 12, 2010) (rejecting defense's suggestion that remote VCT adult witness testimony should only be allowed in cases where medical reasons physically prevent witnesses from traveling or where testifying live would affect psychological well-being of witness).

82. Lubanga, Case No. ICC-01/04/01-06, Redacted Decision on the Defence Request for a Witness To Give Evidence via Video-Link, ๆ 15. 
In fact, in Prosecutor v. Bemba Gombo, the ICC explained that Rule 67 permits remote VCT witness testimony "whenever necessary, provided that the Statute and the Rules are respected and that such measures are not prejudicial to, or inconsistent with, the rights of the accused." 83 The court noted that the rights granted to the accused according to Article 67(1)(e) of the Rome Statute are to "examine or have examined the witnesses against him or her." 84 Because VCT technology permits the witness to be examined by the defense at the time the witness is testifying remotely in court, ${ }^{85}$ the court stated that the rights granted to an accused are therefore not compromised by remote testimony. ${ }^{86}$

83. Bemba, Case No. ICC-01/05-01/08-947, Redacted Decision on the "Request for the Conduct of the Testimony of Witness CAR-OTP-WWWW-0108 by Video-Link," II 10.

84. Id. I 11 (internal quotation marks omitted). Although an earlier draft of the Rome Statute guaranteed an accused the right to "confront and cross-examine" witnesses, the final draft adopted the text of Article 14(3)(e) of the International Covenant on Civil and Political Rights and, pursuant to Article 67(1)(e), guarantees an accused the right "[t]o examine, or have examined, the witnesses against him or her." William A. Schabas, Rights of the Accused, in COMMENTARY ON THE ROME STATUTE OF the International Criminal COURT: OBSERvers' Notes, ARTiCle by ARTiCle 845, 859 (Otto Tiffterrer ed., 1999). Therefore, the rights granted to an accused under the Rome Statute as concerns examining witnesses are identical to those provided to an accused in the statutes creating the ICTY, ICTR, and SCSL. Compare Rome Statute, supra note 77, art. 67(1)(e), with supra notes 43, 53, 70 (discussing the similar provisions of the ICTY, ICTR, and SCSL).

85. Reports indicate that the ICC technology allowing for remote VCT witness testimony functioned well during trials. See Duane W. Krohnke, International Criminal Court: Recent Developments in Other ICC Investigations and Cases, DWKCOMMENTARIES, (Nov. 11, 2011, 4:53 AM) http://dwkcommentaries.wordpress.com/ 2011/11/18/international-criminal-court-recent-developments-in-other-icc-

investigations-and-cases/ (reporting by ICC Deputy Prosecutor on developments in the ICC and noting that some witnesses in the situation for the Democratic Republic of the Congo (DRC) testified by way of video-link from the DRC without any technical problems).

86. See Bemba, Case No. ICC-01/05-01/08-947, Redacted Decision on the "Request for the Conduct of the Testimony of Witness CAR-OTP-WWWW-0108 by Video-Link," - 1-2, 12 (granting request to permit prosecution witness to testify remotely by VCT because of witness's personal circumstances, which appear from the redacted decision to have required his presence at important work); see also Prosecutor v. Bemba Gombo, ICC-01/05-01/08-2101-Red2, Public Redacted Decision on the "Prosecution Request To Hear Witness CAR-OTP-PPPP-0036's Testimony via VideoLink," ๆ 9-10 (Feb. 3, 2012) (permitting prosecution witness to testify remotely by VCT given witness's health status and because the defense's ability to appropriately question the witness would "mitigate any prejudice to the accused's rights as enshrined in Article 67(1)(e) of the Statute"). 


\section{B. Remote VCT Prosecution Testimony in Federal Courts in the United States}

This subpart focuses on federal court decisions, rather than state court decisions, because in the United States, maritime piracy is a crime under federal law. ${ }^{87}$ Accordingly, it is the federal courts in the United States that are most likely to face the question of whether to allow adult prosecution witnesses to testify by two-way, live VCT in the types of cases with which this Article is concerned.

Like the international criminal courts, some federal courts in the United States have permitted adult prosecution witnesses to testify remotely in criminal cases. A review of the case law, however, indicates some wariness in allowing prosecution witnesses to testify remotely. Moreover, that review shows that the various federal courts-and even individual judges within those courts-do not necessarily agree on the circumstances under which that testimony is proper.

One reason for this lack of an apparent consensus is the fact that the Supreme Court has not actually taken a case requiring it to decide whether and under what circumstances adult prosecution witnesses are constitutionally permitted to testify by two-way, live VCT in criminal cases. As a result, lower courts are left to interpret other relevant existing Supreme Court precedent to determine the precise nature of a defendant's rights under the Confrontation Clause of the Sixth Amendment to the U.S. Constitution, which grants the accused the right to "be confronted with the witnesses against him." 88 Some federal courts view the Confrontation Clause as essentially guaranteeing the defendant a general right to contemporaneously cross-examine adverse witnesses. ${ }^{89}$ Under this view, a defendant's Confrontation Clause rights do not differ substantially from the fairtrial rights guaranteed to defendants under the rules of the various international criminal courts and the International Covenant on Civil and Political Rights, which grant the accused a right "to examine or have examined" the witnesses against him. ${ }^{90}$ However, some courts in

87. See 18 U.S.C. $§ 1651$ (2006) (stating that piracy as defined by the law of nations is a federal crime).

88. U.S. CONST. amend. VI.

89. See, e.g., Marc Chase McAllister, Two-Way Video Trial Testimony and the Confrontation Clause: Fashioning a Better Craig Test in Light of Crawford, 34 FLA. ST.

U. L. REV. 836, 841-42 (2007) (describing the underlying protections of the Confrontation Clause according to Supreme Court precedents as encompassing a right to cross-examine adverse witnesses and a right to a face-to-face confrontation).

90. See sources cited supra note 84. The European Convention for the Protection of Human Rights and Fundamental Freedoms (ECHR) similarly grants an accused the right "to examine or have examined the witnesses against him." European 
the United States view a defendant's Confrontation Clause rights as including a more specific right to examine witnesses face-to-face in the defendant's physical presence. ${ }^{91}$ Whether a court in the United States is more or less inclined to permit remote prosecution-witness testimony in criminal cases depends in part on the level of significance it attaches to the face-to-face component of the defendant's Confrontation Clause rights. ${ }^{92}$

This subpart discusses the two Supreme Court cases that have so far guided lower federal court decisions on whether to permit adult prosecution witnesses to testify remotely in criminal cases. It then discusses the two different tests that the federal appellate courts have used to determine whether to admit this testimony in light of the Supreme Court's guidance. The subpart concludes by briefly noting some more recent developments in the Supreme Court's jurisprudence as relates to the Confrontation Clause and the question of when adult witnesses might be able to testify remotely by two-way, live video in criminal cases.

1. U.S. Supreme Court Cases Guiding Lower Court Decisions on Whether to Admit Remote Adult Prosecution-Witness Testimony

The Supreme Court cases to which the lower courts have turned for guidance when deciding whether to permit remote adult prosecution-witness testimony are Coy $v$. Iowa ${ }^{93}$ and Maryland $v$. Craig. ${ }^{94}$ Both of those cases addressed the nature of the defendant's Confrontation Clause rights in the context of live testimony by child witnesses during trial, but outside the immediate presence of the defendant. As the discussion of those cases below illustrates, however, the Court has not been exactly consistent-or unanimousin its statements about the nature of a defendant's Confrontation Clause rights and how absolutely the clause requires witnesses to

Convention for the Protection of Human Rights and Fundamental Freedoms art. 6(3)(d), June 1, 2010, C.E.T.S. No. 5, amended by Protocol Nos. 11, 14. The ECHR was adopted in 1950 and entered into force in 1953. All forty-seven member states of the Council of Europe have ratified it. See David HaRris, Michael O'Boyle \& Colin WARBRICK, LAW OF THE EUROPEAN CONVENTION ON HUMAN RIGHTS 1-2 (2d ed. 2009).

91. See, e.g., United States v. Yates, 438 F.3d 1307, 1312-14 (11th Cir. 2006) (en banc) (holding that the accused has a right to physical face-to-face confrontation).

92. Compare United States v. Gigante, 166 F.3d 75, 80-81 (2d Cir. 1999) (disagreeing with defendant that Sixth Amendment Confrontation Clause rights could only be preserved by "face-to-face confrontation with [witnesses] in the same room"), with Yates, 438 F.3d at 1315-16 (suggesting that the Confrontation Clause grants the defendant a "right to face-to-face physical confrontation" that can only be denied in certain limited circumstances and indicating that "confrontation through a video monitor is not the same as physical face-to-face confrontation").

93. 487 U.S. 1012 (1988).

94. 497 U.S. 836 (1990). 
testify face-to-face in the physical presence of the defendant in criminal cases.

\section{a. Coy v. Iowa}

In Coy v. Iowa, the Supreme Court reversed a sexual-assault conviction, concluding that the lower court's decision to permit two child witnesses to testify behind a large screen where they could not see the defendant violated the defendant's Confrontation Clause rights. ${ }^{95}$ In reaching this conclusion, Justice Scalia, writing for the majority, stated: "We have never doubted ... that the Confrontation Clause guarantees the defendant a face-to-face meeting with witnesses appearing before the trier of fact." ${ }^{66}$ Justice Scalia suggested that requiring witnesses to physically face the defendant serves several important purposes, including making it less likely that witnesses will lie since "[i]t is always more difficult to tell a lie about a person to his face than behind his back."97 Furthermore, even if the witness does lie, Justice Scalia suggested that the lie would be less convincing when recited in the presence of the defendant and the trier of fact. ${ }^{98}$ Thus, he stated that like a less explicit component of the Confrontation Clause, which gives the defendant the right to cross-examine his accuser, the component granting the defendant the right to face-to-face confrontation also serves to "ensur[e] the integrity of the fact-finding process." ${ }^{99}$

Even though the Court found that the defendant's Confrontation Clause rights were violated in the instant case, Justice Scalia nevertheless recognized that the "rights conferred by the Confrontation Clause are not absolute, and may give way to other important interests." ${ }^{100}$ It declined to provide particulars, but the Court stated that any exceptions to the Confrontation Clause protections "would surely be allowed only when necessary to further an important public policy." 101 However, because there had been "no individualized findings that these particular witnesses needed special protection," the Supreme Court held that the lower court's decision to permit them to testify behind a screen "could not be sustained by any conceivable exception."102

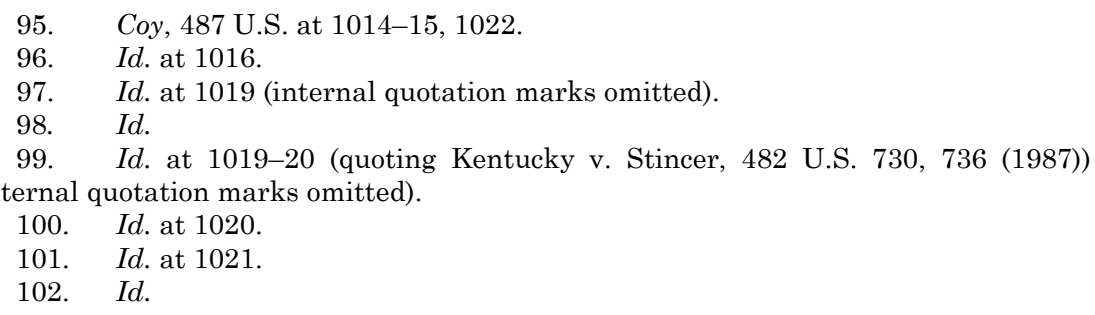


It bears noting that in Coy, four Justices wrote or joined in separate concurring or dissenting opinions to voice some disagreements with the majority's reasoning as it related to the nature and extent of the rights afforded defendants under the Confrontation Clause. ${ }^{103}$ In her concurring opinion in which Justice White joined, Justice O'Connor emphasized that any right conferred by the Confrontation Clause requiring the witness to face the defendant physically was not absolute. ${ }^{104}$ She noted that the Court had stated on many prior occasions that the "[c]lause reflects a preference for face-to-face confrontation at trial" and that the "preference may be overcome in a particular case if close examination of competing interests so warrants."105 She further suggested that most state laws protecting child witnesses would be unaffected by the Court's opinion and should not raise substantial Confrontation Clause problems because those laws typically provide for testimony by one- or two-way, closed-circuit television, which means that testimony is essentially in the presence of the defendant. ${ }^{106}$

The dissent written by Justice Blackmun, and in which Chief Justice Rehnquist joined, took issue with the Coy majority's conclusion that the plain language of the Confrontation Clause was meant to ensure that the witness testify face-to-face in the physical presence of the defendant. ${ }^{107}$ Those Justices argued instead that the Clause's primary purpose is to ensure that defendants are permitted to cross-examine the witnesses against them. ${ }^{108}$ To support their argument, the dissent referenced Supreme Court precedent recognizing "that the Confrontation Clause was designed to prevent the use of ex parte affidavits, to provide the opportunity for crossexamination, and to compel the defendant to stand face to face with the jury."109 Justice Blackmun further referenced the work of John Henry Wigmore, who argued that the very existence of the hearsay rule demonstrated that the right to confrontation is provided not so

103. See id. at 1022-35 (O'Connor and White, JJ., concurring, and Blackmun, J., and Rehnquist, C.J., dissenting).

104. Id. at 1024 (internal quotation marks omitted).

105. Id. (quoting Ohio v. Roberts, 448 U.S. 56, 63-64 (1980)) (internal quotation marks omitted).

106. Id. at 1023-24 (quoting Roberts, 448 U.S. at 63-64) (internal quotation marks omitted).

107. See id. at 1021; id. at 1028 (Blackmun, J., and Rehnquist, C.J., dissenting) (arguing that the Court's "apparent fascination with the witness' ability to see the defendant" will lead to sacrifice of other more important confrontation interests).

108. See id. at 1029 (Blackmun, J., and Rehnquist, C.J., dissenting) (analyzing Supreme Court precedent discussing the Confrontation Clause right in terms of the right to cross-examine).

109. Id. at 1028 (quoting California v. Green, 399 U.S. 149, 158 (1970)) (internal quotation marks omitted). 
that the witness and defendant can "gaze" upon each other, but instead to allow for cross-examination. ${ }^{110}$

\section{b. Maryland v. Craig}

Just two years later, in Maryland v. Craig, the Supreme Court again addressed the question of whether the Confrontation Clause permitted a child witness to testify live during a trial, but outside of the presence of the defendant. ${ }^{111}$ This time, Justice O'Connor wrote for the majority and Justice Scalia wrote for the dissent. ${ }^{112}$ In Craig, the Court held that permitting a child witness to testify by one-way, closed-circuit television, outside the defendant's presence, did not violate the Confrontation Clause. ${ }^{113}$ Justice O'Connor's majority opinion explained that the Supreme Court has "never held... that the Confrontation Clause guarantees criminal defendants the absolute right to a face-to-face meeting with witnesses against them at trial."114 Rather, consistent with the reasoning reflected in her Coy concurrence, Justice O'Connor stated the Court's "precedents establish that the Confrontation Clause reflects a preference for faceto-face confrontation at trial ... that must occasionally give way to considerations of public policy and the necessities of the case." 115 Justice O'Connor went on to explain that despite the preference for face-to-face confrontation, "[t]he central concern of the Confrontation Clause is to ensure the reliability of the evidence against a criminal defendant by subjecting it to rigorous testing in the context of an adversary proceeding before the trier of fact."116

In light of these principles, the Craig Court stated a two-part test for determining when a defendant's confrontation rights will not be violated, even absent a physical, face-to-face meeting at trial with the witnesses against him. First, there must be a case-specific finding that the denial of physical face-to-face "confrontation is necessary to further an important public policy."117 Second, the testimony's

\footnotetext{
110. Id. at 1029 (quoting 5 J. WIGMORE, EVIDENCE $§ 1395$, at 150 (1974)).

111. See Maryland v. Craig, 497 U.S. 836, 849 (1990) (stating the question of the case).

112. Joining in the majority opinion written by Justice O'Connor were Chief Justice Rehnquist and Justices White, Blackmun, and Kennedy. Id. at 840-60. Joining in the dissent written by Justice Scalia were Justices Brennan, Marshall, and Stevens. Id. at $860-70$.

113. Id. at 852-53, 855 (majority opinion). In Craig, the child witness testified in a separate room in the courthouse in the presence of the attorneys, and the testimony was displayed by way of a video monitor to the courtroom in which the judge, jury, and defendant were present. See id. at 841-42.

114. Id. at 844 .

115. Id. at 849 (internal quotation marks omitted).

116. Id. at 845 .

117. Id. at 850,856 .
} 
reliability "must be otherwise assured." 118 As to the reliability of the testimony, the Court indicated that the Confrontation Clause guaranteed the defendant the following: (1) a personal examination of witnesses, (2) who testify under oath, (3) subject to crossexamination, and (4) in a manner that permits the trier of fact to observe the witness's demeanor, hence aiding in an assessment of the witness's credibility. ${ }^{119}$ Applying the two-part test to the case before it, the Craig Court held that the state might have made a casespecific showing that permitting the child witness to testify by oneway, closed-circuit testimony was necessary to further the important state interest of protecting child witnesses in child abuse cases from the trauma of testifying before their abusers, and remanded the case to the court of appeals for that determination. ${ }^{120}$ In addition, the Court found that the procedure used to permit the child to testify assured the reliability of the evidence presented against the defendant because the child testified under oath, the defendant was permitted the "full opportunity for contemporaneous crossexamination," and the judge, jury, and defendant were able to view the child's demeanor-albeit by video—during the testimony. ${ }^{121}$

2. Federal Circuit Split on the Proper Test to Apply in Determining When to Permit Adult Prosecution Witnesses to Testify by TwoWay, Live VCT

The discussion above shows that the Supreme Court's interpretation of the Confrontation Clause allows room for remote testimony and that any face-to-face requirement under the Confrontation Clause may yield under certain circumstances, so long as other rights, such as the right to cross-examine witnesses, are preserved. However, neither Coy nor Craig involved the question of whether to allow adult prosecution witnesses to testify by two-way, live VCT in criminal cases. Accordingly, this subpart examines the two different approaches that federal circuit courts have taken since the Supreme Court's decision in Craig to determine whether and when adult prosecution witnesses may testify remotely in criminal cases consistent with a defendant's Confrontation Clause rights. In United States $v$. Gigante, the Second Circuit Court of Appeals concluded that "[u]pon a finding of exceptional circumstances... a trial court may allow a witness to testify via two-way closed-circuit television when this furthers the interest of justice."122 The Eleventh

118. Id. at 850

119. Id. at $845-46$.

120. Id. at 860 .

121. Id. at 851 .

122. United States v. Gigante, 166 F.3d 75, 81 (2d Cir. 1999). 
Circuit in United States v. Yates, however, concluded that Craig's test for determining the propriety of one-way, closed-circuit testimony applied equally to determining the permissibility of two-way, live VCT prosecution witness testimony. ${ }^{123}$ Thus, the Eleventh Circuit decided that permitting a prosecution witness to testify by two-way, live VCT violates the defendant's Confrontation Clause rights unless the court concludes that remote testimony is "necessary to further an important public policy... and the reliability of the testimony is otherwise assured."124 This subpart discusses both of these cases in more detail below. ${ }^{125}$

In Gigante, the Second Circuit found no violation of a defendant's Confrontation Clause rights when the trial court permitted a mob informant dying of inoperable cancer to testify from a remote location by two-way, live VCT against an alleged boss of the Genovese crime family who was also too ill to travel. ${ }^{126}$ The court explicitly rejected the defendant's argument that the Sixth Amendment entitled him to a face-to-face confrontation with the witness against him "in the same room." 127 It also refused to apply the Craig test, explaining that the test in Craig was "crafted ... to constrain the use of one-way closedcircuit television, whereby the witness could not possibly view the defendant."128 Indeed, the court stated that the two-way videoconferencing procedure "preserved the face-to-face confrontation celebrated by Coy." 129 Furthermore, it found that the two-way video procedure was sufficient to satisfy the Confrontation Clause's central concern of ensuring the reliability of the evidence against a criminal defendant: the witness "was sworn; he was subject to full crossexamination; he testified in full view of the jury, court, and defense

123. See United States v. Yates, 438 F.3d 1307, 1313 (11th Cir. 2006) (en banc) (stating that Craig supplies the proper test).

124. See id. at 1314 (restating the Craig test applied to the two-way video system at hand).

125. This discussion is limited to consideration of only these two cases in detail because they were the only two where courts actually decided what test should apply to the question of whether adult witnesses can testify for the prosecution in a criminal case by two-way, live VCT. I do not discuss in detail here the cases that involved adult witness testimony, but where the question was limited to determining whether the lower court's decision violated clearly established federal law. See Gigante, 166 F.3d at 81. I also do not discuss here in detail the other circuit court cases that considered the question of allowing child witnesses to testify remotely in sexual-assault cases. See generally Maryland v. Craig, 497 U.S. 836 (1990) (discussing the precedent on remote testimony by child witnesses to sexual assaults).

126. Gigante, 166 F.3d at 79-81.

127. Id. at 80

128. Id. at $80-81$.

129. Id. at 81 . 
counsel; and [he] gave [his] testimony under the eye of the [the defendant] himself." 130

Given the constitutional protections afforded by two-way video, the Gigante court decided that a more appropriate test for determining when this remote testimony is proper should be based on the standard used to admit Federal Rules of Criminal Procedure Rule 15 deposition testimony at trial-an "exceptional circumstances" test. ${ }^{131}$ The "exceptional circumstances" to introduce a Rule 15 deposition as substantive evidence at trial exist when the "witness's testimony is material to the case and if the witness is unavailable to appear at trial."132 The court thus reasoned that under the circumstances of the case before it, the trial court could have admitted the dying witness's testimony via a Rule 15 deposition. ${ }^{133}$ Yet, it also pointed out that the closed-circuit video presentation of the witness's testimony that the trial court used instead actually afforded the defendant greater confrontation rights than if "the bare transcript of the [witness's] deposition" had been admitted at trial against him. ${ }^{134}$ The court concluded that it made little sense to adopt a stricter standard than the one articulated by Rule 15 to assess the propriety of introducing two-way, live VCT at trial, holding that such testimony was constitutionally permitted when the court makes a finding of "exceptional circumstances."135 Those "exceptional circumstances" were present according to the Second Circuit Gigante court because the witness's health prevented him from traveling and because the defendant's health also prevented him from participating in a distant deposition. ${ }^{136}$

By contrast, in Yates, the Eleventh Circuit held that the trial court's decision to allow two Australian nationals to testify remotely from Australia against two defendants in a criminal trial in Alabama violated the defendants' Confrontation Clause rights, notwithstanding that the witnesses were beyond the government's

130. Id. at 80. During the trial, video screens transmitted the witness's image to the court, the jury, defense counsel, and the defendant. The witness could also see and hear all courtroom participants on a video screen at his location. Id.

131. Id. at 81

132. Id. (internal quotation marks omitted). Rule 15(a)(1) of the Federal Rules of Criminal Procedure states: "A party may move that a prospective witness be deposed in order to preserve testimony for trial. The court may grant the motion because of exceptional circumstances and in the interests of justice." FED. R. CRIM. P. 15(a)(1).

133. See Gigante, 166 F.3d at 81 (stating that the lower court judge could have admitted the testimony under Rule 15 without violating the Confrontation Clause).

134. See id. (stating that, had the transcript of a Rule 15 deposition been used in court, the defendant would not have had any opportunity to visually assess the witness's demeanor).

135. Id.

136. Id. at $81-82$. 
subpoena powers. ${ }^{137}$ Even though the case before it involved two-way, live VCT, the Yates court held that the Craig test, rather than the Gigante test, applied to the question of whether the remote testimony violated the defendants' confrontation rights. ${ }^{138}$ In fact, the Eleventh Circuit noted that the Second Circuit was the only federal appeals court to make a distinction between one- and two-way video testimony in its Confrontation Clause analysis. Other courts, instead, applied the Craig test in deciding whether to allow child witnesses to testify by two-way, live VCT. ${ }^{139}$

More specifically, the Yates court disagreed with the government's assertion that two-way video provides greater protections of a defendant's confrontation rights than does a Rule 15 deposition, and that two-way video testimony should therefore be admitted under the same standard as Rule 15 depositions. ${ }^{\mathbf{1 4 0}}$ The court reasoned that because the defendant can be present at Rule 15 depositions, those proceedings do not result in any denial of the defendant's constitutional rights to a "physical face-to-face confrontation." 141 On the other hand, the court stated "the simple truth" that "confrontation through a video monitor is not the same as physical face-to-face confrontation." 142 It therefore held that "[t]he Sixth Amendment's guarantee of the right to confront one's accuser is most certainly compromised when the confrontation occurs through an electronic medium." 143

To further support its conclusion that the Craig test governed the situation before it, the Eleventh Circuit relied on the fact that in 2002, the Supreme Court refused to recommend to Congress a proposed amendment to Rule 26 of the Federal Rules of Criminal Procedure that would have explicitly permitted video testimony in "exceptional circumstances."144 Under Proposed Rule 26(b), federal courts would have been able to authorize two-way, live VCT from a remote location in criminal cases "in the interest of justice" when the

137. United States v. Yates, 438 F.3d 1307, 1309-10 (11th Cir. 2006) (en banc).

138. Id. at $1312-13$.

139. See id. at 1313-14 (referencing cases in the Sixth, Eighth, Ninth, and Tenth Circuits where courts applied the Craig test in determining whether to admit two-way, live VCT testimony of child witnesses in sexual-abuse cases).

140. See id. at 1314 (rejecting the government's argument that Craig should govern).

141. Id.

142. Id. at 1315 .

143. Id. The Yates court did not use the precise words in the Confrontation Clause, which grant an accused the right "to be confronted with" witnesses, rather than a right "to confront" witnesses. U.S. CONST. amend. VI.

144. Yates, 438 F.3d at 1314; see also Proposed Amendments to the Federal Rules of Criminal Procedure (Apr. 29, 2002) (appendix to statement of Breyer, J.) [hereinafter Proposed Rule 26(b)], http://www.fedcrimlaw.com/members/keyweb/FRCP-2002.pdf (providing the text of the proposed amendment referenced in Yates). 
requesting party established (1) "exceptional circumstances for such transmission", (2) the transmission used "appropriate safeguards", and (3) the witness was otherwise "unavailable" to attend the trial in person. ${ }^{145}$ In its Committee Notes, the Advisory Committee emphasized that Proposed Rule 26(b) should have satisfied the various interests of the parties to the proceeding and also protected the defendant's Confrontation Clause rights. ${ }^{146}$ However, as the Eleventh Circuit emphasized in Yates, a majority of the Supreme Court refused to approve the amendment, and it was not adopted.

However, it was not only the Supreme Court's refusal to recommend the amendment that seems to have influenced the Eleventh Circuit's decision in Yates. The majority also seems to have placed great weight on a separate statement filed by Justice Scalia, wherein he indicated that the proposed amendment was of "dubious validity under the Confrontation Clause."147 Justice Scalia argued that the Craig test should apply and limit the use of remote testimony in criminal cases to instances in which there had been a case-specific showing that it was "necessary to further an important public policy."148 Of course, as the dissent in Yates pointed out, Justice Scalia's statement has no official legal weight and may not reflect the reasoning of the remaining Justices in the majority who refused to recommend Proposed Rule 26(b). ${ }^{149}$ Furthermore, although the Yates majority makes no mention of it, Justices Breyer and O'Connor filed a dissenting statement indicating that they failed to see Confrontation Clause issues with the proposed amendment to

145. Proposed Rule 26(b), supra note 144, at 7. The proposed rule defined unavailability by reference to Rule 804(a)(4)-(5) of the Federal Rules of Evidence, which essentially states that witnesses are unavailable either if they are dead or infirm, or if the person seeking the witness's testimony is unable to procure it by process or other reasonable means. See FED. R. EvID. 804(a)(4)-(5). As one commentator has noted, Proposed Rule 26(b) can be faulted for simply incorporating Rule 804(a)'s standards of unavailability. For example, Rule 804(a)(4) deems a witness unavailable if he is dead, but obviously a dead witness cannot testify remotely. See Friedman, supra note 4, at 708-11 (explaining how Proposed Rule 26(b)'s incorporation of Federal Rules of Evidence 804(a)(4)-(5) "breed[s] confusion").

146. See Proposed Rule 26(b), supra note 144, at 8-12 (explaining how the rule's various procedures and safeguards allow the amendment to be a "prudent and measured step"). 1).

147. Yates, 438 F.3d at 1314-15 (quoting Proposed Rule 26(b), supra note 144, at

148. Id. at 1315 (quoting Proposed Rule 26(b), supra note 144, at 1-2).

149. Id. at 1324-25 n.8 (Tjoflat, Marcus \& Birch, JJ., dissenting) (stating that Justice Scalia's comments represent "nothing more than the legal musings of a Supreme Court Justice on an issue that has yet to be briefed and argued in a case or controversy before the Court"). In his dissent, Judge Tjoflat further remarked that Justice Scalia's suggestion that the proposed amendment was of "dubious validity" is a statement that "easily can be made of every constitutional challenge the Supreme Court elects to hear." Id. 
Rule 26 since under Rule 15 the trial court could otherwise constitutionally admit an absent witness's nonvisual deposition testimony against a criminal defendant. ${ }^{150}$ Nevertheless, it appears that Justice Scalia's statement did persuade the Eleventh Circuit that it should be wary of taking anything but a very strict approach toward admitting remote video testimony.

Thus, for all of the foregoing reasons, the Yates court concluded that prosecution witnesses could testify by remote two-way, live VCT only when allowing that procedure would "further an important public policy" and when "the reliability of the testimony is otherwise assured." 151 Applying this test, the court found that the first prong was not met in the case before it. ${ }^{152}$ The district court had made casespecific findings that video testimony was necessary to further the important public policies of (1) providing the fact finder with crucial evidence from witnesses who were beyond the court's subpoena power and otherwise unwilling to travel to the United States to testify and (2) resolving the case expeditiously and justly. ${ }^{153}$ The Eleventh Circuit, however, held that although "presenting the fact-finder with crucial evidence is, of course, an important public policy," under the circumstances of the case, including the possibility of a Rule 15 deposition in Australia with all necessary parties present, ${ }^{154}$ "the prosecutor's need for the videoconference testimony to make a case and to expeditiously resolve it are not the type of public policies that are important enough to outweigh the Defendants' rights to confront

150. See Proposed Rule 26(b), supra note 144, at 4 (statement of Breyer, J.) ("It is not obvious how video testimony could abridge a defendant's Confrontation Clause rights in circumstances where an absent witness' testimony could be admitted in nonvisual form via deposition regardless.").

151. Yates, 438 F.3d at 1314-15. Yates, however, was not a unanimous decision, with three judges dissenting from the court's opinion. Id. at 1319-36 (Tjoflat, Birch \& Marcus, JJ., dissenting); id. at 1327-36 (Marcus, Tjoflat \& Birch, JJ., dissenting).

152. Id. at $1315-16$ (majority opinion).

153. Id.

154. Id. at 1316. The court stated that the record did not provide any evidentiary support explaining why the defendants and the witnesses could not all participate in a pretrial deposition in Australia, especially given that under Rule 15, the government must pay the cost of attendance for defendants who cannot themselves afford to pay. Furthermore, although it addressed the fact that foreign countries have refused entry to some defendants wishing to appear at Rule 15 depositions, it noted there was no finding in this case showing that the defendants could not travel to Australia to be present for a deposition. Id. at 1317-18 (referencing United States v. McKeeve, 131 F.3d 1, 7-9 (1st Cir. 1997), wherein the defendant was not permitted to attend a Rule 15 deposition because he was in custody and the United Kingdom refused to assume temporary custody of him). As mentioned above, the court also disagreed with the government that permitting the defendant to cross-examine witnesses against him by two-way, live video testimony during trial in the presence of the court and jury provided greater Confrontation Clause protections than did permitting the defendant to attend an in-person, pretrial deposition. Id. at 1318. 
their accusers face-to-face." 155 Having thus decided that the first prong of the Craig test was not met, the Yates court did not address whether the reliability prong was satisfied..$^{156}$

\section{The Supreme Court After Craig: Some Confrontation Clause} Guidance, but No Resolution of the Circuit Split

Because the Supreme Court has not decided a case directly addressing the question of whether and when the Confrontation Clause permits the introduction of two-way, live VCT for adult prosecution-witness testimony against defendants in criminal cases, the exact formulation of any U.S. rule for allowing such testimony remains unknown at this time. The Supreme Court has, however, offered some additional guidance on the nature of the protections afforded defendants by the Confrontation Clause. It has also issued a statement in connection with a denial of a petition for certiorari indicating that Craig may not "obviously answer[]" whether two-way, live VCT witness testimony is permissible in criminal cases. ${ }^{157}$ Both of these developments are discussed below.

First, in 2004, the Supreme Court decided Crawford $v$. Washington, wherein it held that out-of-court testimonial statements could only be admitted against a defendant in a criminal trial if the witness was unavailable and the defendant had a prior opportunity for cross-examination. ${ }^{158}$ To reach its conclusion, the Crawford Court

155. Id. at 1316 .

156. Id. at 1318. Contrary to the Yates court, but on similar facts, the Florida Supreme Court applied the Craig test and concluded that permitting two Argentine nationals living in Argentina to testify remotely using two-way, live VCT did not violate the defendant's confrontation rights. See Harrell v. State, 709 So. 2d 1364 (Fla. 1998). In Harrell, the court found three important public policies that would be furthered by allowing the testimony: (1) the witnesses "lived beyond" the court's subpoena power; (2) one witness was too sick to travel to the United States; and (3) the testimony of these two victim-witnesses was essential to the case and necessary to the important state interest in resolving criminal matters expeditiously and justly. $I d$. at 1369-70. It further concluded that the second part of the Craig test was satisfied because (1) "the witnesses were placed under oath by a court clerk in Miami"; (2) the defense was able to cross-examine the witnesses; and (3) the jury could observe the witnesses and the witnesses could observe the jury during their testimony. Id. at 1371. In reviewing a subsequent federal habeas petition, the Eleventh Circuit held (several years before deciding Yates) that the Florida Supreme Court's application of the Craig test to the facts before it did not violate clearly established federal law. Harrell v. Butterworth, 251 F.3d 926, 931-32 (11th Cir. 2001); see also Horn v. Quarterman, 508 F.3d 306, 320 (5th Cir. 2007) (finding no violation of clearly established federal law where trial court allowed terminally ill witness to testify by remote two-way VCT since the state's interest in protecting seriously ill witnesses could satisfy Craig's necessity prong).

157. Wrotten v. New York, 130 S. Ct. 2520, 2520 (2010).

158. See 541 U.S. 36, 68 (2004) (explaining the demands of the Sixth Amendment). 
overruled Ohio $v$. Roberts, which held that a hearsay declarant's outof-court statement could be admitted at trial against a defendant without violating the Confrontation Clause as long as (1) the declarant is "unavailable" to testify at trial and (2) the prior out-ofcourt statement bears "adequate indicia of reliability." 159 Such reliability under Roberts could be inferred when the evidence fell within a "firmly rooted hearsay exception" or when the evidence was shown to be otherwise trustworthy. ${ }^{\mathbf{1 6 0}}$ The Crawford Court, however, held that reliability must be assessed "in a particular manner: by testing in the crucible of cross-examination"-as opposed to by some judicial determination of reliability..$^{161}$

Although the Crawford decision dealt only with out-of-court pretrial witness statements, some commentators have suggested that the Confrontation Clause analysis in that case may implicitly limit the Court's holding in Craig. ${ }^{\mathbf{1 6 2}}$ Recall that Craig held that a witness could testify at trial outside the defendant's immediate presence without violating the defendant's rights to be confronted with adverse witnesses when "the reliability of the testimony is otherwise assured" - a test that Crawford concluded was improper. ${ }^{163}$ Those commentators thus suggest that the Craig test for permitting witnesses to testify outside of the direct presence of the defendant might be constitutionally suspect after Crawford because the Craig test uses a "reliability of the evidence" standard. ${ }^{164}$

While those commentators correctly point out the Crawford Court's retreat from the "reliability" standard, there is nevertheless reason to conclude that the Craig test is not constitutionally suspect. Although the Craig Court used the reliability language, its focus, like

159. 448 U.S. 56, 66 (1980).

160. Id.

161. Crawford, 541 U.S. at 61-62.

162. See, e.g., G. Michael Fenner, Today's Confrontation Clause (After Crawford and Melendez-Diaz), 43 CREighton L. REV. 35, 88-89 (2009) ("The problem with the holding from Craig is that fourteen years later, in Crawford, the Court's interpretation of the Confrontation Clause changed radically."); McAllister, supra note 89, at 868 (highlighting a particular passage in the Crawford case as a suggestion that "an overwhelming majority of the current Supreme Court Justices would find the Craig test constitutionally suspect").

163. Maryland v. Craig, 497 U.S. 836, 850-51 (1990). It bears noting, however, that the Yates decision was rendered after the Supreme Court's decision in Crawford, yet the Eleventh Circuit adopted the Craig test and did not suggest that Crawford had rendered it inapplicable. In fact, the majority specifically stated that Crawford would not govern the question of whether a prosecution witness could constitutionally testify remotely during trial because it applies only to "testimonial statements made prior to trial." United States v. Yates, 438 F.3d 1307, 1314 n.4 (11th Cir. 2006) (en banc).

164. McAllister, supra note 89, at 868; see also Fenner, supra note 162, at 88-89 (suggesting that Craig's holding was called into question by Crawford's Confrontation Clause analysis, which indicated that "reliability of the testimony" can only be assured by cross-examination, not by any other method). 
the Crawford Court, was on cross-examination as an important component of reliability as relates to a defendant's rights pursuant to the Confrontation Clause. ${ }^{165}$ The Craig Court specifically stated that permitting the witness to testify at trial by one-way video satisfied Confrontation Clause concerns because in the absence of a face-toface confrontation, "the presence of the[] other elements of confrontation-oath, cross-examination, and observation of the witness' demeanor-adequately ensures that the testimony is both reliable and subject to rigorous adversarial testing in a manner functionally equivalent to that accorded live, in-person testimony."166 Indeed, even the Gigante court focused on the defendant's ability to cross-examine the witness who was testifying remotely in that case in determining that the procedure satisfied Confrontation Clause concerns. ${ }^{167}$ Therefore, while commentators may be correct that the Supreme Court will retreat from Craig's reliability of the evidence standard post-Crawford, for the purposes of this Article one can assume that cross-examination will remain an important-perhaps the most important-factor in assessing whether the Confrontation Clause is satisfied should a witness be permitted to testify by twoway, live VCT. It is beyond the scope of this Article to attempt to predict the precise standard the Supreme Court will adopt to test the admissibility of such testimony, if and when the Court is presented with the question.

Indeed, it appears that the Supreme Court may be inclined at some future date to take up the question, though its most recent guidance indicates only that Craig may not provide the proper test for determining when two-way, as opposed to one-way, remote video testimony can be admitted without violating the Confrontation Clause. In Wrotten v. New York, the Supreme Court denied a petition for certiorari because of the interlocutory posture of the appeal. ${ }^{168} \mathrm{In}$ a separate statement, however, Justice Sotomayor stated that the petition presented the important question of whether a defendant's Confrontation Clause rights "were violated when the State introduced testimony at his trial via a two-way video that enabled the testifying witness to see and respond to those in the courtroom, and vice versa." 169 She explained that in Craig, the Court recognized that "a

165. Craig, 497 U.S. at 851.

166. Id.

167. See United States v. Gigante, 166 F.3d 75, 80 (2d Cir. 1999) (finding that the remote procedure used to present the witness's testimony preserved the defendant's rights to confrontation since the witness was sworn; testified in view of the jury, the court, defense counsel, and the defendant; and was subjected to crossexamination).

168. Wrotten v. New York, 130 S. Ct. 2520, 2520 (2010).

169. Id. In the underlying case from which the petition arose, the New York Court of Appeals had concluded that (1) permitting an elderly and ill witness to testify 
defendant's right to confront accusatory witnesses may be satisfied absent a physical, face-to-face confrontation at trial," but only upon a case-specific finding that the denial of such confrontation is "necessary to further an important public policy."170 Justice Sotomayor concluded that the question raised in the petition was "not obviously answered" by Craig because "the use of video testimony in [Wrotten] arose in a strikingly different context than in Craig." 171 Although one could conclude from this statement that any new test would be less restrictive since two-way remote video testimony more closely simulates live, in-person testimony than one-way video testimony does, Justice Sotomayor's statements are open to interpretation. Again, it is beyond the scope of this Article-which is focused broadly on proposing a test that can be used in courts throughout the world-to predict what test the Supreme Court will ultimately adopt for testing the constitutionality of permitting prosecution witnesses to testify remotely by two-way, live VCT.

\section{The Problem of Modern Maritime Piracy and the NeEd to Encourage States to Use the Available Laws to Prosecute Pirates Instead of Releasing Them}

Having outlined generally some approaches taken by various international criminal courts and by federal courts in the United States to analyze the issue of whether to permit adult prosecution witnesses to testify remotely at trial using two-way, live VCT, this Article now moves to a discussion of the modern piracy problem and the reluctance of states to prosecute. In particular, it discusses how issues relating to the difficulties associated with mounting cases of such international proportions and which involve evidence, suspects, victims, and witnesses from around the globe have negatively impacted states' willingness to prosecute piracy cases. This Article

remotely by two-way, live VCT was necessary to further the important public policy of protecting the well-being of such a witness so that criminal cases could be justly resolved, and (2) the procedures employed ensured the reliability of the witness's testimony. People v. Wrotten, 923 N.E.2d 1099, 1101-03 (N.Y. 2009).

170. Wrotten, 130 S. Ct. at 2520 (quoting Craig, 497 U.S. at 850) (internal quotation marks omitted).

171. Id. On May 27, 2010, the New York First Department Appellate Division ruled on the pending issue that had prevented the Supreme Court from finding a "final judgment" from which a petition for certiorari could be taken. People v. Wrotten, 901 N.Y.S.2d 265 (N.Y. App. Div. 2010); see also Wrotten, 130 S. Ct. 2520 (denying certiorari on interlocutory appeal in light of the procedural difficulties in reviewing the case at that stage). The defendant thereafter filed another petition for certiorari, which was also denied, but without any written statement. Wrotten v. New York, $131 \mathrm{~S}$. Ct. 1020 (2011). 
further addresses how a rule allowing remote prosecution-witness testimony in some circumstances can better facilitate the prosecution of these cases and also encourage more states to undertake the burden of bringing pirates to justice.

\section{A. The Continuing Threat of Modern Maritime Piracy}

The continuing threat of pirate attacks on ships and crews makes traveling in the world's shared sea lanes increasingly dangerous. According to the International Maritime Bureau (IMB) Piracy Reporting Centre, between January 2007 and December 2011, pirates staged some 1,850 attacks worldwide. ${ }^{172}$ During the last three years, the number of attacks has remained above 400 per year-a number that exceeds the number of reported attacks in 2007 by approximately 50 percent. ${ }^{173}$ In fact, from January to March 2011, reports showed that Somali pirates had already staged ninety-seven attacks-more than one per day during that time period.174 In addition, most pirate attacks now involve the use of weapons. ${ }^{175}$ Pirates used guns in 245 attacks in 2011 (more than half of the total number of attacks that year), but they used guns in only seventy-two attacks in 2007 (about 25 percent of the total number of attacks in that year). ${ }^{176}$ Nor are the attacks without victims. In 2007, pirates held some 292 crew members hostage. But, in each year thereafter, more than 800 crew members have been held captive while pirates negotiated their release. ${ }^{177}$ Finally, the ransoms paid to pirates "have increased sevenfold in the last five years": average ransoms increased from about $\$ 600,000$ in 2007 to about $\$ 5$ million in $2011 .{ }^{178}$ In other words, over time, the threat of modern maritime piracy is increasing, rather than decreasing. ${ }^{179}$

172. See ICC-IMB 2011 Report, supra note 11, at 5-6 (providing graphical break-downs of piracy attacks between January 2007 and December 2011).

173. Id.

174. Foreign Affairs Committee, Piracy off the CoAst of Somalia, Report, 2010-12, H.C. 1318, at 11 (U.K.) [hereinafter FoREIGN AFFAIRS CommitTeE 2012 REPORT].

175. ICC-IMB 2011 Report, supra note 11, at 20.

176. Id. at 11

177. Id. In total, between 2007 and 2011, pirates have held over 3,500 seafarers hostage. They killed about sixty-two of their victims during that time period. ForeIGN AFFAIRS COMMITTEE 2012 REPORT, supra note 174, at 16.

178. Foreign AFFAIRS COMMITTEe 2012 REPORT, supra note 174, at 55-56. Some ransoms recently paid to Somali pirates have been significantly higher. For example, in November 2010, a band of pirates was paid about $\$ 10$ million in ransom to release a South Korean supertanker, the Samho Dream. See Jeffrey Gettleman, Money in Piracy Attracts More Somalis, N.Y. Times, Nov. 9, 2010, at A10.

179. In fact, the number of actual pirate attacks is likely greater than the number reported to the IMB since most believe that ship owners have incentives to 
Moreover, the threat of modern maritime piracy is broad in its reach. As Rear Admiral Brian M. Salerno explained, "[A] single piratical attack affects the interests of numerous countries, including the flag State of the vessel, various States of nationality of the seafarers taken hostage, regional coastal States, owners' States, and cargo shipment and transshipment States." 180 The evidence from 2011 alone supports the Rear Admiral's statement. The IMB reported that in 2011, pirates attacked ships bearing the flags of fifty-six different countries ${ }^{181}$ in the waters off the coasts of Somalia, Indonesia, Malaysia, the Philippines, Singapore, Vietnam, Bangladesh, India, Benin, and Nigeria, among other places:182 "As of 31 December 2011, suspected Somali pirates held 11 vessels for ransom with 193 crew members of different nationalities as hostage." 183

A brief description of just two pirate attacks can help illustrate the multinational reach of maritime piracy. On February 9, 2011, pirates attacked the Greek supertanker MV Irene 900 miles off the coast of Somalia. When attacked, the MV Irene was carrying 2 million barrels of Kuwaiti oil destined for the United States and estimated to be worth $\$ 200$ million. The twenty-five-member crew included seventeen Filipinos, seven Greeks, and one Georgian. ${ }^{184}$ Some two months after being taken hostage, and after the pirates received an astounding $\$ 13.5$ million ransom payment, the ship, cargo, and crew were released. ${ }^{185}$ On April 8, 2011, just one day after the hostages

underreport for fear their ships will be delayed for investigations or that their insurance premiums will rise. See JoHn S. BuRneTt, DANGEROus WATERS: MoDERN Piracy and Terror on the High Seas 181 (2003); Peter Chalk, The Maritime Dimension of InTERnational SECURITY: TERRorism, Piracy, AND Challenges For THE UNITED STATES 7-8 (2008) (noting several variables that are "directly relevant to the general surge in piracy over the last fifteen years").

180. Piracy Against U.S.-Flagged Vessels: Lessons Learned: Hearing Before the Subcomm. on Coast Guard \& Mar. Transp. of the H. Comm. on Transp. \& Infrastructure, 111th Cong. 79 (2009) (statement of Rear Admiral Brian M. Salerno, Assistant Commandant for Marine Safety, Security, and Stewardship, Dep't of Homeland Sec., U.S. Coast Guard).

181. See ICC-IMB 2011 Report, supra note 11, at 15-16 (providing a graphic breakdown of the various flag states that experienced pirate attacks between 2007 and 2011).

182. Id. at $5-6$.

183. Id. at 20

184. E.g., EU NAVFOR Public Affairs Office, MV Irene SL Pirated in the North Arabian Sea, EU NAVFOR (Feb. 9, 2011), http://www.eunavfor.eu/2011/02/mv-irene-slpirated-in-the-north-arabian-sea/; Tom Scott, Somali Pirates: Steep Rise in Attacks, NEWs-INSURANCES (Mar. 28, 2011), http://www.newsinsurances.co.uk/somali-piratessteep-rise-in-attacks/0169475872.

185. Anna Bowden \& Shikha Basnet, Oceans Beyond Piracy, The Economic Cost of Somali Piracy 2011, at 11 (One Earth Future Foundation, Working Paper), available at http://oceansbeyondpiracy.org/sites/default/files/economic_cost_of_piracy_2011.pdf. 
from the $M V$ Irene were released, ten pirates stormed the $M V$ Susan $K$, a German cargo ship registered in Antigua \& Barbuda. The $M V$ Susan $K$ was attacked thirty-five miles off the coast of Oman while travelling from Mumbai to Port Sudan with a crew that included four Ukrainians and six Filipinos. ${ }^{186}$ Seventy days after being captured, and after pirates received an approximately $\$ 4$ million ransom payment, the $M V$ Susan $K$ and its crew were released. ${ }^{187}$

\section{B. The International Law Authorizing Piracy Prosecutions}

International law provides many legal tools for prosecuting acts of maritime piracy. Piracy is the oldest crime to which universal jurisdiction applies, ${ }^{188}$ and all states may punish acts of piracy occurring on the high seas even if the state has no specific nexus to the offense. ${ }^{189}$ Exercising universal jurisdiction over acts of maritime piracy is warranted because of the general heinousness of the crime and the fact that it is directed against ships and persons of any and all nations-disrupting international trade and commerce. ${ }^{190}$ Thus, states may use their own domestic laws to prosecute and punish those who commit the crime of maritime piracy, regardless of the nationalities of either the suspected pirates or their victims. ${ }^{191}$

186. Somali Pirates Release Greek Owned VLCC, Hijack German Cargo Ship the Next Day, MAR. ExECUTIVE (Apr. 11, 2011), http://www.maritime-executive.com/ article/somali-pirates-release-greek-owned-vlcc-mv-irene-sl.

187. Andrew Mwangura, Ransom Reported Paid for MV Susan K, SOMALIA REP. (June 17, 2011), http://www.somaliareport.com/index.php/post/981/Ransom_ Reported_ Paid_for_MV_Susan_K.

188. Universal jurisdiction is defined as "criminal jurisdiction based solely on the nature of the crime, without regard to where the crime was committed, the nationality of the alleged or convicted perpetrator, the nationality of the victim, or any other connection to the state exercising such jurisdiction." THE PRINCETON PRINCIPLES ON UNIVERSAL JURISDICTION 28 (Stephen Macedo ed., 2001).

189. See Cohen, supra note 9, at 201 (explaining that the doctrine of universal jurisdiction was originally developed to address acts of maritime piracy occurring on the high seas outside of any state's territorial jurisdiction).

190. See, e.g., Kenneth C. Randall, Universal Jurisdiction Under International Law, 66 TEX. L. REV. 785, 794 (1988) (suggesting that the heinous nature of piracy offenses, which involve violence and depredation, and the fact that piracy is directed against ships of all nations, provide the most accurate rationale for allowing the exercise of universal jurisdiction over piracy). In United States v. Cargo of Brig Malek Adhel, 43 U.S. (2 How.) 210 (1844), the U.S. Supreme Court recognized the pirate as an enemy of all mankind over whom states could exercise universal jurisdiction because the pirate "commits hostilities upon the subjects and property of any or all nations, without any regard to right or duty, or any pretence of public authority." Id. at 232.

191. See Anthony J. Colangelo, The Legal Limits of Universal Jurisdiction, 47 VA. J. INT'L L. 149, 150-51 (2006) (highlighting the fact that universal jurisdiction attaches to crimes of piracy); see also 4 WILLIAM BLACKSTONE, COMMENTARIES 72 (9th ed. 1783) (describing actions that have been historically deemed "piracy"); M. Cherif Bassiouni, Universal Jurisdiction for International Crimes: Historical Perspectives and 
Universal jurisdiction over piracy offenses is codified in an international treaty-the UNCLOS ${ }^{192}$ - to which most states belong. ${ }^{193}$ Pursuant to Article 105 of UNCLOS, any state may seize pirate ships and arrest and prosecute pirates. ${ }^{194}$ Article 101 lists the acts which constitute piracy and over which states may exercise universal jurisdiction as follows:

(a) any illegal acts of violence or detention, or any act of depredation, committed for private ends by the crew or the passengers of a private ship or a private aircraft, and directed:

(i) on the high seas, against another ship or aircraft, or against persons or property on board such ship or aircraft;

(ii) against a ship, aircraft, persons or property in a place outside the jurisdiction of any State;

(b) any act of voluntary participation in the operation of a ship or of an aircraft with knowledge of facts making it a pirate ship or aircraft;

(c) any act of inciting or of intentionally facilitating an act described in subparagraph (a) or (b). ${ }^{195}$

In addition, under Article 103, a ship is a pirate ship "if it is intended by the persons in dominant control to be used for the purpose of committing one of the acts referred to in Article 101."196

In sum, UNCLOS essentially defines piracy as (1) an illegal act of violence or detention, (2) committed for private ends, (3) on the high seas, and (4) directed against another ship. ${ }^{197}$ In addition, under Article 100, states are actually required to cooperate in the repression

Contemporary Practice, 42 VA. J. INT'L L. 81, 110-11 (2001) ("Positive international law in the twentieth century has clearly established universal jurisdiction for piracy.").

192. UNCLOS, supra note 10, arts. 100-108, 110.

193. See supra note 10 and accompanying text.

194. UNCLOS, supra note 10, art. 105.

195. Id. art. 101.

196. Id. art. 103.

197. Although UNCLOS broadly defines piracy, it includes only those attacks that occur on the high seas or outside the territory of any state. Id. art. 101(a). Thus, UNCLOS is not applicable to attacks that occur in territorial waters and ports. In such cases, only the nation in whose territory the attacks occurred will have jurisdiction to prosecute using UNCLOS. See id. art. 2(2) ("The sovereignty of a coastal State extends... to an adjacent belt of sea, described as the territorial sea."). Otherwise, states would have to use other legal tools-such as the Convention for the Suppression of Unlawful Acts Against the Safety of Maritime Navigation (SUA Convention) - to prosecute acts of piracy that occurred in the territorial waters of another state. See Convention for the Suppression of Unlawful Acts Against the Safety of Maritime Navigation arts. 3, 6, Mar. 10, 1988, 1678 U.N.T.S. 221 [hereinafter SUA Convention] (defining piracy and the signatory states' jurisdictions). 
of piracy to the fullest possible extent, ${ }^{198}$ a mandate which in theory suggests they should assist in the arrest and prosecution of pirates.

The Convention for the Suppression of Unlawful Acts Against the Safety of Maritime Navigation (SUA Convention) ${ }^{199}$ addresses some additional acts of maritime violence not covered by UNCLOS. ${ }^{200}$ Drafted in response to the Achille Lauro incident when Palestinian terrorists hijacked an Italian cruise liner, ${ }^{201}$ the SUA Convention prohibits both completed attacks on ships and attempts to do the same. ${ }^{202}$ Under Article 3 of the SUA Convention, a prohibited offense is committed by anyone who (1) "seizes or exercises control over a ship by force or threat thereof or any other form of intimidation,"203 (2) "performs an act of violence against a person on board a ship if that act is likely to endanger the safe navigation of that ship," 204 or (3) attempts to do any of the above. ${ }^{205}$ Unlike UNCLOS, the SUA Convention extends the definition of piracy to include attacks within territorial or archipelagic waters or in port, ${ }^{\mathbf{2 0 6}}$ as long as the ship is scheduled for international navigation. ${ }^{207}$

198. UNCLOS, supra note 10, art. 100 ("All States shall cooperate to the fullest possible extent in the repression of piracy on the high seas or in any other place outside the jurisdiction of any State.").

199. SUA Convention, supra note 197.

200. See, e.g., Rapporteurs of the Defence Committee, The Role of the European Union in Combating Piracy, 12, 21, European Security and Defence Assembly, Assembly of Western European Union, ESDA Doc. A/2037 (June 4, 2009) ("The SUA Convention aims at suppressing unlawful acts against maritime safety . . not covered by [UNCLOS] ....”); Joseph M. Isanga, Countering Persistent Contemporary Sea Piracy: Expanding Jurisdictional Regimes, 59 AM. U. L. REV. 1267, 1292 (2010) ("The SUA [Convention] attempts to address forms of maritime violence that are not included in the UNCLOS definition.").

201. Rosario Domínguez-Matés, From the Achille Lauro to the Present Day: An Assessment of the International Response to Preventing and Suppressing Terrorism at Sea, in International LEgal Dimension OF TERrorism 231 (Pablo Antonio Fernández-Sánchez ed., 2009); see also, e.g., Malvina Halberstam, Terrorism on the High Seas: The Achille Lauro, Piracy and the IMO Convention on Maritime Safety, 82 AM. J. INT'L L. 269, 269-72 (1988) (describing the Achille Lauro hijacking and the incident's impact on maritime terrorism law).

202. See SUA Convention, supra note 197, art. 3 (establishing a number of offenses that involve the endangerment of ships, including attempts to commit any of the listed offenses).

203. Id. art. 3(1)(a).

204. Id. art. 3(1)(b).

205. Id. art. 3(2)(a).

206. Cf. id. art. 4 (extending the Convention's application to all ships scheduled to navigate beyond the territorial seas of a single state).

207. Id. Nevertheless, although the SUA Convention theoretically covers acts of violence against persons on a ship while in port, those acts must also be "likely to endanger the safe navigation of that ship." Id. art. 3(1)(b). Because of this language, using the SUA Convention to prosecute attacks while a ship is docked may be difficult. 
On the other hand, in contrast to UNCLOS, the SUA Convention does not provide for the exercise of universal jurisdiction. ${ }^{208}$ Only signatory states may prosecute violations of the SUA Convention, and they need some nexus to the offense in order to do so. States may only prosecute using the SUA Convention when (1) the offense was against a ship flying its flag, (2) the offense occurred in its territory, (3) the offense was committed by a national of the state, or (4) a national of the state was a victim of the offense. ${ }^{209}$ Accordingly, if a signatory state with the required nexus to the offense refuses to prosecute, or if the states with a nexus to the offense have not ratified the SUA Convention, pirates and maritime terrorists will go unpunished notwithstanding the SUA Convention's increased territorial coverage. $^{210}$

\section{The Tendency to Release, Rather than Prosecute, Captured Pirates}

Despite this international legal framework authorizing statesand, indeed, encouraging them-to prosecute maritime piracy offenses, states are more inclined to release the pirates they capture than to try them in their own domestic courts. Since 2008, numerous states have provided ships, crew, money, and technology to support a variety of naval forces that conduct counter-piracy operations in the Gulf of Aden and the Indian Sea. The multinational naval force CTF150 was the first to conduct counter-piracy operations in late 2008. In January 2009, it was replaced by another multinational naval force, CTF-151. ${ }^{211}$ In 2008, the European Union launched its own combined naval force (Operation Atalanta) aimed at "deterr[ing], prevent[ing], and repress[ing] acts of piracy and armed robbery" in the seas off the coast of Somalia. ${ }^{212}$ Since 2008, the North Atlantic Treaty Organization has sent ships to the Horn of Africa to conduct counterpiracy operations. ${ }^{213}$ Other countries have independently sent their

208. See, e.g., Isanga, supra note 200, at 1292 ("The SUA [Convention] . . did not extend the scope of universal jurisdiction."); Eugene Kontorovich, Recent Case, United States v. Shi, 525 F.3d 709 (2008), 103 AM. J. INT’L L. 734, 738 (2009) (“[T]he SUA Convention does not create universal crimes.").

209. SUA Convention, supra note 197, art. 6.

210. See George D. Gabel, Jr., Smoother Seas Ahead: The Draft Guidelines as an International Solution to Modern-Day Piracy, 81 TUL. L. REV. 1433, 1445 (2007) (discussing limits of jurisdiction granted by the SUA Convention).

211. Lauren Ploch et AL., Cong. Research Serv., R40528, Piracy off the HORN OF AFRICA 22 (2010), available at http://www.scribd.com/doc/47456778/Piracy-offthe-Horn-of-Africa-Apr-2010-CRS-R40528.

212. Council Decision 2008/918/CFSP, 2008 O.J. (L 330) 19-20 (EU), available at http://eur-lex.europa.eu/LexUriServ/LexUriServ.do?uri=OJ:L:2008:330:0019:0020:EN:PDF (approving Operation Atalanta).

213. See PlOCH ET AL., supra note 211, at 23 (summarizing the North Atlantic Treaty Organization (NATO) Operation Ocean Shield). 
own naval forces to the region to provide escorts to ships and to engage in antipiracy operations. ${ }^{214}$ According to a recent report, during 2011, "over 30 countries contributed military forces to counterpiracy operations in the Gulf of Aden and Indian Ocean," and the likely number of naval ships patrolling those areas on any given day has been between ten and sixteen. ${ }^{215}$

To their credit, the naval forces deployed by states have had some success in both repressing pirate attacks and capturing pirates. According to the report by Jack Lang, the UN Secretary-General's Special Advisor on Legal Issues Relating to Piracy off the Coast of Somalia, naval forces "thwarted 126 attacks in 2008, 176 in 2009 and 127 in 2010." 216 As for 2011, the IMB reports that although Somali pirates apparently staged 237 attacks, the number of successful hijackings decreased due, at least in part, to the naval forces' antipiracy patrols. ${ }^{217}$ Furthermore, the navies have captured many of the pirates who attacked vessels at sea. Reports indicate that between January and August 2009 alone, naval patrols captured 517 pirates and killed ten. ${ }^{218}$

Yet, while the navies have contributed to a decrease in the rate of successful hijackings, they have not been able to "contain the growth in the overall number of attacks and the area in which pirates can operate."219 Many blame the prevalence of the navies' "catch and release" policies to help explain why pirate attacks are not becoming less frequent despite the antipiracy efforts of the world's navies. ${ }^{220}$ For example, in 2008, the Danish navy released ten suspected Somali

214. See id. (discussing the naval forces of India, China, and Russia).

215. Bowden \& Basnet, supra note 185, at 24-25.

216. Lang, supra note 12 , ๆ 39.

217. ICC-IMB 2011 Report, supra note 11 , at 20

218. PLOCH ET AL., supra note 211, at 22.

219. FOREIGN AFFAIRS COMMITTEE 2012 REPORT, supra note 174, at 3; see also Lang, supra note 12, 39 (noting that the number of pirate attacks from 2007-2010 has continued to grow despite the presence of naval forces).

220. See S.C. Res. 1918, ๆ 1, U.N. Doc. S/RES/1918 (Apr. 27, 2010) (stating that "the failure to prosecute persons responsible for piracy and armed robbery at sea" was undermining the international community's antipiracy efforts); U.N. SecretaryGeneral, Report of the Secretary-General on Possible Options To Further the Aim of Prosecuting and Imprisoning Persons Responsible for Acts of Piracy and Armed Robbery at Sea off the Coast of Somalia, Including, in Particular, Options for Creating Special Domestic Chambers Possibly with International Components, a Regional Tribunal or an International Tribunal and Corresponding Imprisonment Arrangements, Taking into Account the Work of the Contact Group on Piracy off the Coast of Somalia, the Existing Practice in Establishing International and Mixed Tribunals, and the Time and Resources Necessary To Achieve and Sustain Substantive Results, ๆ 9, U.N. Doc. S/2010/394 (July 26, 2010) [hereinafter S/2010/394 Report] ("In order to be effective, naval operations apprehending suspects should result in prosecutions. The risk otherwise is that suspects are released at sea, or repatriated, and return to commit further acts of piracy or armed robbery at sea."). 
pirates, even though they were armed and had notes on them stating how they would split their piracy proceeds. ${ }^{221}$ The United Kingdom's and Canada's naval forces have both been accused of releasing suspected pirates. ${ }^{222}$ In fact, within a one-month period in 2010 , the United Kingdom's Royal Navy vessels found suspected pirates on board three different motherships with hostages, but thereafter released not only the hostages, but also the suspected pirates. ${ }^{223}$ From mid-August to mid-December 2010, the European Union's naval forces, Operation Atalanta, captured fifty-one suspected pirates whom it immediately freed. ${ }^{224}$ In May 2010, the United States released ten pirates it had been holding for weeks after concluding that no nation was willing to undertake the burden of prosecuting them. ${ }^{225}$ In fact, according to the Lang Report, only about one-third of the pirates captured between 2008 and 2010 were prosecuted. ${ }^{226}$ As dismal as that number may seem, the numbers only get worse. Mr. Lang explained that at the beginning of 2011, the rate of prosecution had dropped to about 10 percent of captured pirates with "more than 90 per cent of the pirates apprehended by States patrolling the seas [being] released without being prosecuted." ${ }^{227} \mathrm{He}$ emphasized that

221. Paula Prada \& Alex Roth, On the Lawless Sea, It's Not Easy Putting Somali Pirates in the Dock, WALL ST. J. (Dec. 12, 2008), http://online.wsj.com/article/ SB122903542171799663.html; see also Oliver Hawkins, What To Do with a Captured Pirate, BBC News (Mar. 10, 2009, 10:49 AM), http://news.bbc.co.uk/2/hi/7932205.stm (discussing the 2008 capture and release of the ten pirates).

222. See Canadian Warship Helps U.S.-Flagged Vessel Evade Pirates off Somalian Coast, GUELPH MERCURY, May 22, 2009, available at 2009 WLNR 9831454 (discussing Canada's lack of jurisdiction over suspected pirates); Jason Groves, Navy Gives Somali Pirates Food and Water... Then Lets Them Sail off Scot Free, MAILONLINE (Jan. 27, 2010, 7:46 PM), http://www.dailymail.co.uk/news/article1246300/Navy-gives-pirates-food-water--lets-sail-scot-free.html (describing several incidents when suspected pirates were released).

223. See ForEIGN AFFAIRS COMMITTEE 2012 REPORT, supra note 174, at Ev 4344 (questioning of Mr. Henry Bellingham, Minister of Parliament) (explaining why the United Kingdom has not brought any pirates back to the United Kingdom for prosecution).

224. Lang, supra note 12 , ๆ 43.

225. Craig Whitlock, Navy Releases Accused Somali Pirates Held on Warship for Six Weeks, WASH. Post (May 28, 2010, 6:18 PM), http://www.washingtonpost.com/wpdyn/content/article/2010/05/28/AR2010052804108.html.

226. Lang, supra note 12 , 143.

227. Id. at I 14. In his testimony before the UK Parliament, Minister Bellingham suggested that the 90 percent release rate is somewhat misleading since not all cases in which suspected pirates are captured would be worthy of prosecution due to insufficient evidence that a crime has been committed. Captain David Reindorp noted the difficulty of producing evidence of piracy in cases where suspected pirates are caught near shore with AK47s, but no other evidence to prove they are pirates, as opposed to simple fisherman carrying arms for protection. See FOREIGN AFFAIRS COMMITTEE 2012 REPORT, supra note 174, at Ev 43-44 (discussing the challenges of distinguishing between pirates, hostages, and fishermen). The United Kingdom's 
the "catch and release" policy has become the rule, rather than the exception. ${ }^{228}$

Thus, although the evidence indicates the naval fleets have contributed to counter-piracy efforts, the full deterrent effect of those resources likely cannot be realized absent a significant increase in prosecution rates. ${ }^{29}$ Consider, for example, how the 10 percent prosecution rate might affect the cost-benefit calculations of an ordinary Somali male making the decision of whether to become a pirate. Some economists estimate that "the average pirate could earn between $\$ 33,726$ and $\$ 78,840$ a year, depending on the ransom paid"-an amount of money which far exceeds the $\$ 500$ annual per capita GDP of Somalia. ${ }^{230}$ While the remuneration to pirates is obviously higher than what a Somali male could otherwise earn, being a pirate also includes some risks of death or imprisonment. But, if the risks of imprisonment are as low as they are presently, the decision to choose piracy necessarily becomes easier. ${ }^{231}$ Indeed, the "catch and release" policies send the message that "crime can pay," and the evidence shows that some pirates get that message inasmuch as they return to the crime of piracy after they have been apprehended and released.232 The 2012 UK House of Commons Foreign Affairs Committee Report makes the point well:

Foreign Affairs Committee, however, responded to the Minister's testimony by pointing out:

$[\mathrm{N}]$ ot all claims made by the Government about the difficulty in securing evidence were wholly convincing: when pirates are observed in boats with guns, ladders and even hostages, it beggars belief that they cannot be prosecuted, assuming that states have the necessary laws in place and the will to do so.

Id. at 45 .

228. See Lang, supra note 12, I 43-44 (discussing the frequency at which suspected pirates are released without prosecution).

229. Deterrence and the prevention of future criminal activity are primary goals of criminal prosecutions. See Harmelin v. Michigan, 501 U.S. 957, 1007-08 (1991) (Kennedy, J., concurring) (noting that deterrence is one of the "first purposes of criminal law"); M. Cherif Bassiouni, Combating Impunity for International Crimes, 71 U. COLO. L. REV. 409, 410 (2000) (noting that one of the purposes of pursuing justice and accountability is that doing so "contributes to the prevention and deterrence of future conflicts").

230. Geopolicity, The Economics of Piracy: Pirate Ransoms \& Livelihoods OFF THE COAST OF SOMALIA 12 tbl.1 (2011), available at http://www.geopolicity.com/ upload/content/pub_1305229189_regular.pdf.

231. See Foreign AfFAIRs COMMITTEe 2012 RePort, supra note 174, at 3 ("[T] $]$ he risk to pirates of serious consequences is still too low to outweigh the lucrative rewards from piracy.").

232. See Lang, supra note 12, I 14 (stating that some of the very pirates who were previously apprehended and released have thereafter been identified as repeat offenders). 
[S]imply returning suspected pirates to their boats or to land ... may temporarily disrupt their activities, [but it] provides little long term deterrence and has demonstrably failed to prevent an annual increases [sic] in both the number of pirates going to sea and in the number of attacks. ${ }^{233}$

\section{The Need to Encourage More Piracy Prosecutions by Improving Access to Witness Testimony}

Increasing the present ratio of prosecutions as compared to releases can help guarantee that more suspected pirates are brought to justice. It should also help to deter future acts of piracy because increasing prosecution rates will also increase the potential costs of engaging in piracy. As discussed above, the current policy which allows the world's navies to catch and release suspected pirates appears insufficient to stem the threat modern maritime piracy poses to innocent seafarers.

Of course, there are many reasons states may not want to assume the burden of prosecuting piracy cases, some of which have been examined by the author in previous projects. States may fear that if they prosecute pirates in their own territory, any convicted pirates may thereafter seek asylum. ${ }^{234}$ States have also claimed that they do not have the necessary national laws to prosecute acts of piracy. ${ }^{235}$ However, as demonstrated above, international law authorizes states to prosecute acts of piracy even when the state has no particular nexus to the offense. ${ }^{236}$ Accordingly, while the author's own research confirms that some states do not in fact have sufficient national laws enabling them to exercise universal jurisdiction over piracy, the author also concludes there is no particular reason-other than a lack of political will-to explain why states do not, or cannot, have such laws. ${ }^{237}$

This Article addresses the other frequently cited reason to explain why states are not inclined to undertake piracy prosecutions:

233. FOREIGN AFFAIRS COMMITTEe 2012 REPORT, supra note 174, at 40.

234. See Yvonne M. Dutton, Pirates and Impunity: Is the Threat of Asylum Claims a Reason To Allow Pirates To Escape Justice?, 34 FordHAM InT'L L.J. 236, 29295 (2011) (analyzing the texts of several treaties governing asylum and nonrefoulement and concluding that even if there is some small risk that some pirates will be able to claim asylum or other benefits, the problem of maritime piracy is so great that developed nations should assume the risk of those additional asylum claims and hold pirates accountable for their crimes).

235. See Yvonne M. Dutton, Maritime Piracy and the Impunity Gap: Insufficient National Laws or a Lack of Political Will?, 86 TUL. L. REV. 1111, 1133-39 (discussing states' reluctance to prosecute pirates and their failure to implement international piracy conventions).

236. See supra Part IV.B.

237. Dutton, supra note 235, at 1159-62. 
the difficulty and cost of trying cases of an international character that require the state to collect evidence and produce witnesses from different parts of the globe. ${ }^{238}$ As noted in Part IV.A. above, a single pirate attack can involve victims (such as ship owners, cargo owners, and seafarers) from a number of different countries. For countries that require or prefer live witness testimony, undertaking piracy prosecutions is more costly and difficult than it would be if witnesses could, for example, provide their testimony in writing. ${ }^{239}$ And, because states can prosecute-and are encouraged to prosecutepiracy crimes using universal jurisdiction even when they have no direct nexus to the attack, states could find that few, if any, witnesses whose evidence they need for a trial will be state nationals. Even if those witnesses were to agree to travel from their home state and testify at the trial in person, the prosecuting state would still have to incur the burden of paying the travel costs of those witnesses.

Paying travel costs, however, may be a moot issue in many cases because states ordinarily cannot actually compel foreign witnesses to appear at trials. As seasoned federal prosecutor Lynn Helland explains, prosecutors in the United States can only subpoena U.S. citizens or residents to testify live at criminal trials. ${ }^{240}$ But U.S. courts have no subpoena powers over citizens of foreign countries when they are outside the United States. ${ }^{241}$ Prosecutors may still be able to require some foreign witnesses to provide necessary evidence if the United States has entered into a treaty or other agreement with the witness's country by which the foreign country will help obtain that evidence. Even with a treaty, however, the foreign witness cannot be compelled to travel to testify in person; the evidence would be provided in writing, or by some other means. ${ }^{242}$ Likewise, the United Kingdom cannot compel foreign witnesses to testify at

238. See supra Part IV.C.

239. According to the Lang Report, most countries where maritime piracy cases have been brought follow a common-law legal tradition and generally require or prefer in-person witness testimony. See Lang, supra note 12, ๆ 61 (discussing the challenges presented by live testimony requirements).

240. See Helland, supra note 2, at 724 \& n.20 (noting that pursuant to 28 U.S.C. $\S 1783(\mathrm{a})$, U.S. citizens or residents are subject to a court's subpoena power even if they are located outside the country). However, citizens of a foreign country may be served with a subpoena while on U.S. soil. Id.

241. Martin Davies, Bypassing the Hague Evidence Convention: Private International Law Implications of the Use of Video and Audio Conferencing Technology in Transnational Litigation, 55 AM. J. CoMP. L. 205, 232 (2007); see also Helland, supra note 2 , at 724 (stating that citizens of foreign countries can only be compelled to testify in U.S. courts if they can be served with a subpoena while in U.S. territory or if an applicable international agreement exists).

242. See Helland, supra note 2, at 724 (describing the limitations of U.S. authorities' ability to compel witness testimony). 
trials. ${ }^{243}$ In short, in the context of maritime piracy cases, courts could find that many witnesses are beyond their subpoena power, meaning that valuable evidence will be lost unless there is some other way to secure the testimony of those witnesses.

Moreover, there are many reasons why foreign witnesses may not be willing to actually travel to the prosecuting state to give their testimony in person. Some witnesses may be more fearful of reprisals should they be seen testifying in person against suspected pirates. ${ }^{244}$ Some witnesses, such as crew members and naval officers, may conclude that taking leave from work to travel to testify would unnecessarily risk the security of their employment-even if some laws may supposedly require their employers to make them available to testify and to pay their wages while doing so. ${ }^{245}$ Other witnesses may be too ill to travel. ${ }^{246}$ In all of these cases, the state can only hope to persuade the foreign witness to travel to testify since it likely has no power to subpoena a trial appearance. In fact, one of the United Kingdom's naval officers pointed to the unwillingness of witnesses to travel to testify live at trials in an effort to explain, in part, why the United Kingdom had yet to bring any of the pirates it captured back to be prosecuted. ${ }^{247}$ He testified that victims of pirate attacks often claim they do not want to go anywhere to testify against the pirates and that the United Kingdom could not compel foreign nationals to travel from their home countries to testify. ${ }^{248}$

States may be able to persuade some foreign witnesses to attend a trial to testify so that justice may be done. Some foreign witnesses, in fact, must have committed to making themselves available in the various piracy cases that states have prosecuted. ${ }^{249}$ Nevertheless, it

243. See Foreign AfFairs CommitTee 2012 REPorT, supra note 174, at Ev 4445 (testimony of Captain David Reindorp) (explaining that the United Kingdom cannot compel noncitizen hostages to travel to the United Kingdom to testify against the pirates who held them captive).

244. See Lang, supra note 12, \62 (stating that many victims sometimes fear giving live testimony).

245. See id. ๆ $61-62$ (suggesting that Security Council resolution 1950 provides that seafarers must be given an opportunity to give evidence in piracy trials and that employers should enshrine that right in the contracts of seafarers).

246. See, e.g., Harrell v. State, 709 So. 2d 1364, 1370 n.6 (Fla. 1998) (positing that a witness may be too ill to appear away from home in person but may be able to testify via teleconference).

247. See, Foreign AfFAiRs COMMITTEe 2012 REPORT, supra note 174, at Ev 4445 (testimony of Captain David Reindorp) (discussing the difficulties of identifying and prosecuting suspected pirates).

248. Id.

249. For example, data from 2011 indicates that approximately twenty countries have prosecuted, or are in the process of prosecuting, at least one piracy case, and it seems reasonable to assume that not all potential witnesses are nationals of the prosecuting state. See Bowden \& Basnet, supra note 185, at 23 (listing countries holding piracy trials). 
remains true that states exercising universal jurisdiction over piracy cases will likely find that they cannot compel foreign witnesses to attend a trial in the prosecuting state-again, meaning that some evidence will be lost, and some pirates may escape justice as a result. Even in cases where the foreign witnesses voluntarily agree to appear, they may not make themselves available in a timely fashion. Thus, trial delays can be common while courts await witness testimony, a fact that can prejudice the suspected pirates awaiting their day in court. Indeed, Mr. Lang notes in his report that as of early 2011, about 100 suspected pirates were in temporary detention for as many as two years while awaiting sentencing or witness testimony. ${ }^{250}$

The costs and the difficulties associated with obtaining the necessary evidence to prosecute maritime piracy cases can be mitigated if courts in those countries requiring or preferring live witness testimony adopt a more flexible rule that allows some witnesses to testify remotely under certain circumstances. Although foreign witnesses could still not be compelled to testify, states should find it easier to persuade them to testify remotely. After all, by testifying remotely, the witness could avoid the risks and inconveniences that accompany travel and live, in-person testimony in a foreign locale. In addition, states would save the costs of funding witness travel. For all of these reasons, states should also be more willing to assume the burden of prosecuting piracy cases that do not involve their own nationals as direct victims of the attack, thereby reducing the catch-and-release tendency that currently prevails. In fact, Mr. Lang and the House of Commons of the United Kingdom have both encouraged the potential use of two-way, live VCT as a way to alleviate the difficulties associated with obtaining the necessary evidence to successfully prosecute maritime piracy cases.

Part V describes and discusses the author's proposed rule to allow two-way, live VCT witness testimony in maritime piracy trials under certain circumstances.

\section{A Proposal to Allow Two-Way, Live VCT Witness TESTIMONY IN MARITIME PIRACY TRAILS}

Courts should allow witnesses to testify by two-way, live VCT in maritime piracy trials on a case-by-case basis in the interests of justice, upon proof by the requesting party that (1) the testimony is necessary to the fair and just resolution of the case, (2) the witness is unable or unwilling for good reason to travel to the court to testify in 
person, and (3) the transmission will use appropriate safeguards to protect the defendant's rights to a fair trial and to ensure the witness understands his obligation to give truthful testimony. The test is not meant to replace any preference for live testimony, but it should facilitate obtaining evidence in piracy cases in particular instances in which live testimony is simply not a real alternative. Furthermore, the test seeks to ensure that remote testimony is only admitted where it would be in the interests of justice to proceed remotely and when the technology and the circumstances at the remote location replicate as much as possible the courtroom experience, so as to protect the public's and the defendant's interests in a fair trial. The rule addresses only two-way, live VCT-a mode of technology that will permit all parties in the courtroom and in any remote location to see and hear one another at all times. As a result, although the witness is at a remote location, the defendant will still be able to cross-examine the witness contemporaneously during the trial proceedings and in view of the judge and jury.

The proposed test is designed so that remote witness testimony will be permitted only when the court deems it necessary and proper. It requires a case-specific determination and balances the interests of the various parties to the proceeding in deciding whether allowing a particular prosecution witness to testify by remote VCT is in the interests of justice. ${ }^{251}$ It considers the public's interest in ensuring that trials of serious international crimes can proceed with the evidence necessary to a fair and just resolution of the case. It considers the need to protect witnesses against risks or inconveniences associated with having to attend a trial in person. Finally, it considers the defendant's rights to a fair trial, including the right to hear and cross-examine contemporaneously the witnesses against him-witnesses who are also aware of their obligation to speak truthfully. Each prong of the proposed test is discussed in more detail below.

251. See, e.g., supra Part III.A (describing the various tests used by the international criminal courts, all of which permit remote VCT testimony only when in the interests of justice and where the court determines, for example, that the witness is unable or unwilling to attend the trial, the testimony is important, and the accused is not prejudiced in his right to cross-examine or confront the witness); supra Part III.B.1.b. (describing the Craig test, which requires a showing of an important public policy, unavailability of the witness, and that the procedure ensures the evidence is reliable-including that cross-examination is permitted); supra Part III.B.2 (describing the Gigante test, which permitted remote VCT testimony in the interests of justice in light of exceptional circumstances-namely, whether the testimony was material, the witness was unavailable, and the defendant's confrontation rights were still protected). 


\section{A. Testimony Necessary to the Fair and Just Resolution of the Case}

The first prong of the proposed test is designed to protect the interest of the court and the public in ensuring that trials can proceed with the evidence necessary to a fair and just resolution of the case. To be able to testify remotely, the witness's testimony must be sufficiently important to proving or disproving the defendant's guilt. At the same time, however, the proposed test provides a method for courts to obtain that necessary evidence so that maritime piracy trials can go forward and also be resolved. The ICTY and ICTR both expressly consider the importance of the witness's testimony in determining whether to permit remote prosecution testimony. ${ }^{252}$ The Gigante court similarly considered whether the witness's testimony was material in applying its "exceptional circumstances" test to the question of remote adult prosecution-witness testimony. ${ }^{253}$ Courts applying the Craig test likewise indicated that obtaining crucial evidence necessary to justly and expeditiously resolving criminal matters can satisfy the "public policy" prong of that test. For example, in Harrell v. State, the Florida Supreme Court found that two Argentinean witnesses possessed necessary evidence and that their testimony was essential to the important state interests in resolving criminal matters. ${ }^{254}$ Notwithstanding that it concluded that permitting the remote witness testimony in Yates was improper, even the Eleventh Circuit agreed that the "[g]overnment's interest in presenting the fact-finder with crucial evidence is, of course, an important public policy." 255 Indeed, as the Yates dissent pointed out, "providing the fact-finder with reliable testimony and justly resolving the case are the same public policies that were found important enough to warrant the one-way procedure approved in Craig." 256

The international community as a whole should have an interest in making certain that states have the necessary evidence to mount maritime piracy trials. As discussed above, piracy poses an everincreasing threat to individuals, as well as to the safety and security of the world's shared sea lanes and the important resources that travel through those seas. ${ }^{257}$ In fact, in an executive order dated April 12, 2010, President Barack Obama stated that acts of piracy and

252. See supra Part III.A.1-2 (outlining the ICTY's and ICTR's criteria for allowing remote testimony).

253. See supra notes 131-36 and accompanying text (discussing the application of the "exceptional circumstances" test).

254. See supra note 156 (discussing the Harrell case).

255. United States v. Yates, 438 F.3d 1307, 1316 (11th Cir. 2006) (en banc).

256. Id. at 1322 (Tjoflat, Marcus, \& Birch, JJ., dissenting).

257. See supra Part IV.A. 
armed robbery off the coast of Somalia posed an "extraordinary threat to the national security and foreign policy of the United States." 258 The UK House of Commons Foreign Affairs Committee recently made a similar point, explaining that piracy threatens the United Kingdom's economy and security; it affects the country's "banking, insurance and shipping industries, and threatens the large volume of goods which are transported to the [country] by sea." 259 There is little hope that the threat posed by maritime piracy can be halted or pirates deterred unless states can obtain the evidence necessary to prosecute pirates who attack innocent seafarers and hold them and the world's goods hostage.

\section{B. Witness Unable or Unwilling for Good Reason to Testify in Person}

The second prong of the proposed test considers the interests of the witness and witness availability. As discussed in Part IV.D, because maritime piracy is a universal-jurisdiction crime that any state can prosecute without any nexus to the offense, piracy trials can necessarily involve witnesses who are not state nationals. Therefore, the possibility of remote testimony in maritime piracy trials is important because many witnesses will likely be beyond the state's subpoena power or otherwise unwilling to travel great distances at great potential cost to their health, safety, or job security to testify live at a trial in a foreign country.

Furthermore, given the nature of piracy trials and the types of witnesses who may have necessary evidence, this prong's "unable or unwilling for good reason" language should be broadly interpreted. The case law in the international criminal courts and in the United States establishes that a witness's poor health or other health condition, such as pregnancy, is a well-established reason for granting a request to testify by video. ${ }^{260}$ Case law also shows that courts frequently conclude that safety or other concerns that make witnesses extremely vulnerable should they have to testify live in front of the defendant constitute valid reasons to grant a request to

258. Exec. Order No. 13,536, 75 Fed. Reg. 19,869 (Apr. 12, 2010); Exec. Notice, 76 Fed. Reg. 19,897 (Apr. 7, 2011) (continuing Executive Order 13,536). See generally U.N. Office on Drugs and Crime, Testimony to the U.S. H.R. Foreign Affairs Subcomm. on Int'l Orgs., Human Rights and Oversight (May 14, 2009), available at http://www.unodc.org/unodc/en/about-unodc/speeches/2009-14-05.html (discussing the threat of Somali piracy to the stability of the region, and the commercial and security interest of UN Member States).

259. ForEIGN AFFAIRS COMMITTEE 2012 REPORT, supra note 174, at 5.

260. See, e.g., supra notes 39, 54, 68, 126 and accompanying text (discussing pertinent case law). 
testify remotely. ${ }^{261}$ Like the ICC, however, courts should decline to be constrained regarding the circumstances under which they may find a witness has good reasons for being unwilling to attend a trial in person. ${ }^{262}$ Indeed, some courts have found that job-related difficulties are sufficient to establish witness unavailability when considering a request to allow remote testimony. ${ }^{263}$ In the piracy context, it is quite conceivable that concerns relating to job security will prompt some witnesses to conclude that testifying in a foreign country is too risky. As the Lang Report notes, some victims and witnesses of piracy attacks have refused to testify because they are afraid their employers would not give them time off. ${ }^{264}$ Naval personnel may also have some difficulty leaving their tours of duty for the time it might take to travel from sea to a foreign location to testify in person at a trial. ${ }^{265}$

Witnesses should also be deemed unable or unwilling for good reason to testify at trial in person when they are beyond the subpoena power of the foreign court and cannot be persuaded to travel. While it is true that some nations may have procedures like the Rule 15 deposition procedure sometimes used in the United States to preserve the evidence of witnesses who may be unavailable at trial, these procedures are cumbersome and costly. Moreover, despite the Eleventh Circuit's comments in Yates, there is reason to believe that a Rule 15 deposition procedure is not as protective of a defendant's rights as the two-way, live VCT procedure. After all, the Rule 15 procedure allows some depositions to go forward without the defendant's in-person participation and does not permit contemporaneous cross-examination at trial. This Article discusses these points in more detail below.

First, even if a nation has procedures similar to Rule 15's, those procedures can be cumbersome. As the dissent in Yates pointed out, arranging Rule 15 depositions is difficult because one has to deal with travel to a foreign state. Those arrangements, even if ultimately

261. See, e.g., supra notes 55, 81 and accompanying text (discussing pertinent case law).

262. See supra note 81 and accompanying text (discussing the ICC's willingness to allow video testimony when the witnesses' personal circumstances encourage it).

263. See, e.g., supra notes 58, 86 and accompanying text (discussing pertinent case law).

264. See Lang, supra note 12, 61 (discussing the impediments to in-person testimony).

265. See, e.g., Standards of Military Commissions and Tribunals: Testimony Before the H. Armed Servs. Comm., 106th Cong. (2006) (statement of Gerald Gahima, Senior Fellow, U.S. Inst. of Peace), available at http://www.usip.org/publications/ practice-international-criminal-tribunals-and-their-relevance-military-commissionslight-h (noting that substitutes for requiring the live trial testimony of military commanders, for example, can help in the situation where those persons need to remain in the field working). 
successful, can take time and will likely result in trial delays to the prejudice of all parties to the proceeding. ${ }^{266}$ When the suspect is in custody, those arrangements become even more burdensome. Foreign countries do not need to permit suspects who are accused of violent crimes and in custody onto their soil and into their own temporary custody. ${ }^{267}$ And, in the piracy context, it would not be unusual for suspects to be in state custody while awaiting trial given the nature of the violent crimes pirates commit and the fact that the pirates will often not be nationals of the prosecuting state. Accordingly, while taking a deposition of the witness in his home country may be an alternative in some cases, when the defendant cannot attend the deposition, the procedure seems particularly inferior to permitting the witness to testify remotely at the trial.

Second, a deposition that occurs some years, months, or weeks before the actual trial does not provide the same rights of contemporaneous cross-examination, or even confrontation, as does the opportunity to question a witness who appears at the trial by twoway, live VCT. This Part discusses in greater detail below the various ways in which two-way, live VCT mirrors the trial experience when witnesses testify in person. One benefit two-way, live VCT has over procedures allowing for the introduction of previously recorded deposition testimony is that the defense can tailor its crossexamination of prosecution witnesses to what it has learned about the prosecution's case from all of the other evidence produced at trial. ${ }^{268}$

Finally, Rule 15 deposition procedures can be costly for the state. In the maritime piracy context, those costs could be quite substantial since many witnesses with relevant and necessary evidence will likely live in foreign jurisdictions. Not all states will have the resources to fund foreign travel for depositions, and even states with sufficient resources are unlikely to want to fund such travel. States are not embracing their duty to prosecute piracy cases using universal jurisdiction. They are unlikely to change their current behavior unless mounting such prosecutions becomes less-rather than moreburdensome.

It is true that states may not be able to persuade all witnesses who are beyond their court's subpoena powers to testify remotely by two-way, live VCT. Nevertheless, there can be no question that remote testimony is less of a burden on the witness than traveling to a foreign state to testify in person. Thus, it should be the case, as the

266. United States v. Yates, 438 F.3d 1307, 1323 (11th Cir. 2006) (en banc) (Tjoflat, Marcus \& Birch, JJ., dissenting).

267. See United States v. McKeeve, 131 F.3d 1, 7 (1st Cir. 1997) (discussing the difficulties involved in arranging the testimony of a foreign defendant).

268. See id. at 8. (noting that a court would want to consider the importance of having testimony given in the context of the trial, rather than at some earlier date). 
international criminal courts and courts in the United States have found, that many witnesses will agree to suffer the inconvenience of testifying remotely in order help bring pirates to justice.

\section{Transmission and Other Safeguards to Protect Defendant's Fair-Trial Rights}

The third and final part of the proposed test focuses on the interest in ensuring that the trial is fair from the perspective of the defendant-and, indeed, the public. It addresses concerns relating to protecting the defendant's right to be confronted by and be able to cross-examine witnesses who testify against him. It also addresses the need to have other safeguards in place at the remote site so that the witness can testify freely, but with the understanding that testimony must be given truthfully.

First, because the proposed rule contemplates only two-way, live VCT, it already guarantees that the remote testimony will replicate in-person testimony at trial better than one-way modes of transmitting testimony. The two-way, live VCT technology allows testifying witnesses to see and respond to questioning by courtroom participants. The courtroom participants can also see, hear, and respond to the witness. Indeed, the international criminal courts have concluded that defendants' cross-examination rights are not compromised when witnesses testify remotely by two-way, live VCT because the technology permits the defense to examine the witness contemporaneously during the witness's remote testimony at trial. ${ }^{\mathbf{2 6 9}}$ Moreover, even in the United States, the Supreme Court has stated that the Confrontation Clause does not guarantee defendants "the absolute right to a face-to-face meeting with witnesses against them at trial." 270 Two-way, live VCT ensures that the defendant can still cross-examine the witnesses against him, thus satisfying what the Supreme Court has stated to be the most fundamental right protected by the Confrontation Clause. ${ }^{271}$

269. See, e.g., supra note 44 and accompanying text (quoting the ICTY as stating that videoconferencing "respects the right of the accused to cross-examine and directly confront witnesses while observing their reactions"); supra notes 85-86 and accompanying text (explaining that the ICC has concluded that a defendant's rights to cross-examine witnesses would not be compromised where a witness was subject to contemporaneous cross-examination during remote testimony).

270. Maryland v. Craig, 497 U.S. 836, 844 (1990); see also Kweku Vanderpuye, Traditions in Conflict: The Internationalization of Confrontation, 43 CORNELL INT'L L.J. 513, 536 (2010) (suggesting that the United States is virtually alone in viewing confrontation as something of a categorical imperative even where there are other competing factors that show the overall fairness of the trial proceedings).

271. See discussion supra Part III.B.3 (explaining Crawford v. Washington, 541 U.S. $36,61-62(2006))$. 
It is true that not all courts appear to agree that remote witness testimony sufficiently replicates the experience of live testimony in the courtroom. The Yates majority stated the "simple truth" that "confrontation through a video monitor is not the same as physical face-to-face confrontation." ${ }^{272}$ Although that statement is necessarily true since the two methods of testifying are not "identical," the other "simple truth" is that the Supreme Court has stated that the Confrontation Clause does not absolutely guarantee face-to-face confrontation. ${ }^{273}$ Indeed, the Craig Court found that permitting a child witness to testify by one-way, closed-circuit television did not violate the defendant's confrontation rights. Here, the two-way, live VCT procedure more closely simulates the experience of live courtroom testimony than the one-way procedure does since the witness and courtroom participants can see each other. ${ }^{274}$ As previously noted, Professor Lederer has suggested that with improvements in technology, one may have difficulty observing that a remote witness is not actually physically present at the trial. ${ }^{275}$

In addition to the question of the defendant's ability to adequately cross-examine or confront a remote witness, some courts have questioned whether courtroom participants can adequately assess the demeanor of a remote witness. For example, one chamber of the ICTR refused to permit an important witness to testify remotely, citing concerns that it would be unable to sufficiently observe the witness's demeanor-and thus determine credibility. ${ }^{276}$ The chamber's comment, however, should be considered alongside the decisions of many other courts admitting two-way, live VCT after concluding that allowing such testimony would still protect the defendant's rights to a fair trial. Although remote testimony is used less frequently in criminal cases, its more regular use in civil cases suggests that courts are comfortable that the technology can sufficiently convey the image and voice of witnesses to the trier of fact. ${ }^{277}$ In any event, there is little reason to believe that judges and juries cannot assess a witness's demeanor equally well on video as in

272. See supra text accompanying note 142 .

273. Craig, 497 U.S. at 844.

274. See United States v. Yates, 438 F.3d 1307, 1335 (11th Cir. 2006) (en banc) (Marcus, Tjoflat \& Birch, JJ., dissenting) (discussing the benefits of the two-way procedure); see also United States v. Abu Ali, 528 F.3d 210, 242 (4th Cir. 2008) (stating, in a case where witnesses were deposed from Saudi Arabia with defendant in the United States, that the two-way, live deposition procedures used were in some ways more protective of the defendant's confrontation rights than the procedures used in Craig).

275. See supra note 28 and accompanying text.

276. See supra note 62 and accompanying text.

277. See, e.g., supra notes 30-32 and accompanying text (discussing the various uses of VCT in foreign and domestic courts). 
person. In fact, the videoconference procedure may offer the fact finder a better view of the witness depending on the size of the video screen and its placement. ${ }^{278}$ Moreover, some studies have shown that jurors tend to perceive remote witnesses very much like they perceive witnesses who testify live in the courtroom. ${ }^{279}$ Because people around the world are increasingly using video technology to communicate with each other for personal and other reasons, one may expect that judges and jurors will only become increasingly comfortable viewing witnesses remotely.

Finally, the proposed rule only authorizes the use of two-way, live VCT in the interests of justice when steps are taken to make sure the witness at the remote location understands the obligation to give truthful testimony. Accordingly, just as the international criminal tribunals required that witnesses testify in locations such as courtrooms or embassies, so too should courts require remote witnesses in maritime piracy trials to appear at a location that will convey the seriousness of the proceeding. ${ }^{280}$ To guarantee that the witness is not coached at the remote location, courtroom officials or some other neutral officer should oversee remote proceedings. In addition, courts could allow the parties to send a representative to the remote location to act as observers should they wish to do so. ${ }^{281}$ Implementing these procedures in a foreign location will require the assistance of foreign governments. However, because maritime piracy is harming the international community as a whole, and because the foreign state should be grateful another state has assumed the burden of prosecution, one should expect some cooperation from states. Moreover, most states are parties to UNCLOS and have agreed to cooperate to the fullest extent possible in the repression of piracy. ${ }^{282}$ Even though the treaty contains no mechanism to enforce this obligation, the prosecuting state could reference this obligation in an effort to obtain the cooperation of other states to assist in facilitating remote witness testimony.

Finally, so that the remote witness understands the obligation to testify truthfully, the trial court and the courtroom official or other neutral officer should place the witness under oath and inform him

278. See Yates, 438 F.3d at 1334 (Marcus, Tjoflat \& Birch, JJ., dissenting) (noting that the videoconference procedure may make the witness's image easier for the fact finder to observe than had the witness testified in person).

279. See supra note 27 and accompanying text.

280. See supra text accompanying note 47 (discussing ICTY guidelines for the orderly conduct of VCT); supra text accompanying notes 73-76 (discussing SCSL safeguards for remote witness testimony).

281. See supra text accompanying notes 73-76 (allowing for a court representative to be present in a remote courtroom).

282. See supra text accompanying note 198 (discussing states' obligations under UNCLOS). 
that failure to tell the truth could result in a prosecution for perjury or other criminal punishment. ${ }^{283}$ Of course, each state's perjury laws may differ, but many should be sufficient to subject the witness to a perjury prosecution. It bears noting that the Yates and Harrell trial courts administered oaths to the foreign witnesses in Australia and Argentina, respectively. ${ }^{284}$ Furthermore, like the extradition treaty between the United States and Argentina discussed in Harrell, other countries likely have extradition treaties that provide for extradition for the crime of perjury.

\section{CONCLUSION}

Allowing the use of two-way, live remote witness VCT in maritime piracy cases on a case-by-case basis when the proposed rule is satisfied should help to facilitate the prosecution of these cases and help end the impunity gap that currently prevails. States would not have to be worried that they could never obtain the evidence necessary to successfully mount a piracy case because they could offer witnesses the possibility of testifying remotely. The rule ensures that courts permit remote prosecution-witness testimony only when it would further the interests of justice and also protect the defendant's rights to a fair trial. The witness's evidence has to be sufficiently important, so that it is necessary to the fair and just resolution of the case. The witness has to be unable or unwilling to attend the trial for good reason-such as a foreign witness beyond the subpoena power of the state or a witness who would suffer health or job-related risks should he be required to attend a trial in person. Furthermore, even though the witness would not be in the courtroom, the two-way, live VCT technology enables all parties-whether in the courtroom or the remote location - to see and hear one another so that defense counsel can subject the witness to real-time cross-examination and so that the courtroom participants can assess the witness's demeanor at the same time.

The technology necessary to permit two-way, live VCT remote witness testimony is not without cost. However, as noted above, the international criminal courts and the courts in many developed nations are already using the technology. ${ }^{285}$ To the extent that less-

283. See Maryland v. Craig, 497 U.S. 836, 845-46 (1990) (discussing the rights guaranteed by the Confrontation Clause).

284. United States v. Yates, 438 F.3d 1307, 1310 (11th Cir. 2006) (en banc); Harrell v. State, 709 So. 2d 1364, 1371 (Fla. 1998).

285. See supra note 30 and accompanying text (providing examples of courts that use VCT); see also Heru Andriyanto, Court To Allow Video Link Testimony in Bashir Trial, JAKARTA GLOBE (Mar. 11, 2011), http://www.thejakartaglobe.com/ 
developed nations do not have the technology or the necessary funds to obtain it, wealthier nations could assist. After all, the world community is spending more than $\$ 1$ billion each year to support the antipiracy efforts of the various patrolling navies. ${ }^{286}$ Nations are also providing funds to assist Kenya and the Seychelles in developing their courts and prisons so that they can aid in prosecuting pirates. ${ }^{287}$ There seems little reason not to spend some funds on helping nations obtain the technology to allow witnesses to testify remotely using VCT if doing so would also encourage those nations to share the burden of prosecuting piracy cases.

The international community must seek solutions, and sometimes novel solutions, if it hopes to put an end to the current situation in which pirate attacks are ever-increasing in number, in violence, and in payoffs to pirates. International law permits even those states with no nexus to the offense to prosecute pirates, but states are releasing the pirates they capture instead of prosecuting them. They are doing so in part because of the difficulties associated with obtaining evidence from witnesses who are often foreigners beyond the state's subpoena power. The proposed rule offers at least a partial solution to the culture of impunity that currently surrounds piracy. It suggests a less burdensome and less costly way to ensure that states can obtain the necessary evidence to prosecute maritime piracy cases, while at the same time protecting the public's and the defendant's interests in ensuring that trials are conducted in a fair and just manner.

home/court-to-allow-video-link-testimony-in-bashir-trial/427957 (noting that a court in India approved a request to permit sixteen witnesses to testify from a remote location in a trial against cleric Abu Bakar Bahsir by way of video link because of security concerns).

286. David Gauvey Herbert, Piracy Is Down, and Moving Farther Out, NAT'L J., (Apr. 21, 2010, 4:49 PM), http://burnafterreading.nationaljournal.com/2010/ 04/piracyis-down-and-why-thats-b.php (suggesting that the EU, NATO, and U.S. antipiracy operations cost slightly less than $\$ 1.9$ billion per year to support).

287. Kenya and the Seychelles have both made agreements with various countries to accept some arrested pirates for trial. See Denmark, Seychelles in Deal To Prosecute Pirates, REUTERS (May 25, 2011, 3:52 PM), http://af.reuters.com/article/ somaliaNews/idAFLDE74O1RI20110525. The UN Office on Drugs and Crime, with the support from the United Kingdom and others, for example, provides funds to support court and prison facilities in both countries. See, e.g., Foreign AfFairs CommitTeE 2012 REPORT, supra note 174, at Ev 69; Lang, supra note 12, ๆ $65-66$ \& n.37. Kenya, however, has indicated that it will not continue to accept a great number of captured pirates for trial. See, e.g., Jeff Davis, Kenya Cancels Piracy Trial Deals, SundaY NATION (Sept.. 30, 2010, 9:48 PM), http://www.nation.co.ke/News/Kenya+cancels+ piracy+trial+deals/-/1056/1021740/-/yfbkamz/-/index.html (reporting that Kenya had terminated agreements committing to try captured pirates in its courts); Lillian Leposo, Kenya Ends Agreement with EU to Prosecute Suspected Somali Pirates, CNN WORLD (Oct. 4, 2010), http://articles.cnn.com/2010-10-04/world/kenya.eu.pirates_1_ somali-pirates-kenyan-authorities-kenya-s-ministry?_s=PM:WORLD (same). 